\title{
Aerosol properties associated with air masses arriving into the North East Atlantic during the 2008 Mace Head EUCAARI intensive observing period: an overview
}

\author{
M. Dall'Osto ${ }^{1}$, D. Ceburnis ${ }^{1}$, G. Martucci ${ }^{1}$, J. Bialek ${ }^{1}$, R. Dupuy ${ }^{1}$, S. G. Jennings ${ }^{1}$, H. Berresheim ${ }^{1}$, J. Wenger ${ }^{2}$, \\ R. Healy ${ }^{2}$, M. C. Facchini ${ }^{3}$, M. Rinaldi ${ }^{3}$, L. Giulianelli ${ }^{3}$, E. Finessi ${ }^{3}$, D. Worsnop ${ }^{4,5}$, M. Ehn ${ }^{5}$, J. Mikkilä ${ }^{5}$, \\ M. Kulmala ${ }^{5}$, and C. D. O'Dowd ${ }^{1}$ \\ ${ }^{1}$ School of Physics \& Centre for Climate \& Air Pollution Studies, National University of Ireland Galway, Ireland \\ ${ }^{2}$ Department of Chemistry, University College Cork, Cork, Ireland \\ ${ }^{3}$ Istituto di Scienze dell'Atmosfera e del Clima Via Gobetti 101, 40129 Bologna, Italy \\ ${ }^{4}$ Aerodyne Inc., Boston, USA \\ ${ }^{5}$ Department of Physics, University of Helsinki, Helsinki, Finland
}

Received: 31 October 2009 - Published in Atmos. Chem. Phys. Discuss.: 10 December 2009

Revised: 9 April 2010 - Accepted: 17 April 2010 - Published: 7 September 2010

\begin{abstract}
As part of the EUCAARI Intensive Observing Period, a 4-week campaign to measure aerosol physical, chemical and optical properties, atmospheric structure, and cloud microphysics was conducted from mid-May to mid-June, 2008 at the Mace Head Atmospheric Research Station, located at the interface of Western Europe and the N. E. Atlantic and centered on the west Irish coastline. During the campaign, continental air masses comprising both young and aged continental plumes were encountered, along with polar, Arctic and tropical air masses. Polluted-continental aerosol concentrations were of the order of $3000 \mathrm{~cm}^{-3}$, while background marine air aerosol concentrations were between 400 $600 \mathrm{~cm}^{-3}$. The highest marine air concentrations occurred in polar air masses in which a $15 \mathrm{~nm}$ nucleation mode, with concentration of $1100 \mathrm{~cm}^{-3}$, was observed and attributed to open ocean particle formation. Continental air submicron chemical composition (excluding refractory sea salt) was dominated by organic matter, closely followed by sulphate mass. Although the concentrations and size distribution spectral shape were almost identical for the young and aged continen-
\end{abstract}

Correspondence to: C. D. O'Dowd

(colin.odowd@nuigalway.ie)

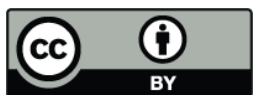

tal cases, hygroscopic growth factors (GF) and cloud condensation nuclei $(\mathrm{CCN})$ to total condensation nuclei $(\mathrm{CN})$ concentration ratios were significantly less in the younger pollution plume, indicating a more oxidized organic component to the aged continental plume. The difference in chemical composition and hygroscopic growth factor appear to result in a 40-50\% impact on aerosol scattering coefficients and Aerosol Optical Depth, despite almost identical aerosol microphysical properties in both cases, with the higher values been recorded for the more aged case. For the $\mathrm{CCN} / \mathrm{CN}$ ratio, the highest ratios were seen in the more age plume. In marine air, sulphate mass dominated the sub-micron component, followed by water soluble organic carbon, which, in turn, was dominated by methanesulphonic acid (MSA). Sulphate concentrations were highest in marine tropical air - even higher than in continental air. MSA was present at twice the concentrations of previously-reported concentrations at the same location and the same season. Both continental and marine air exhibited aerosol GFs significantly less than ammonium sulphate aerosol pointing to a significant organic contribution to all air mass aerosol properties.

Published by Copernicus Publications on behalf of the European Geosciences Union. 


\section{Introduction}

Atmospheric aerosols affect air quality and climate. In terms of air quality, aerosols influence human health, leading to increased mortality ratess and deteriorate visibility (e.g. Pope and Dockery, 2006; Hand and Malm, 2007). In terms of climate, regional haze layers contribute to the direct radiative forcing (the direct radiative effect), directly reducing incoming solar energy, and indirectly (the indirect radiative effect) reducing incoming solar energy through the modification of cloud reflectance (Intergovernmental Panel on Climate Change (IPCC), 2007). In the IPCC climate assessment, emphasis was placed on the complexity of the combined direct and indirect forcing from both aerosols and gases as well as on the importance of improving our understanding of the role that each of these components plays in radiative forcing in an integrated system. Recent work has also suggested that aerosols have been masking the real climate sensitivity to greenhouse gas warming, pointing to an even more important role for aerosols in climate than originally anticipated (Andreae et al., 2005). Such knowledge would reduce the uncertainty in current estimates of radiative forcing and enable a better prediction of the effects of anthropogenic activity on global change. Acquisition of such knowledge is the central aim of the European Commission Framework 7 Integrated Project EUCAARI (European Aerosol Cloud Climate and Air Quality Interactions).

EUCAARI (Kulmala et al., 2009) has two overarching objectives: Objective 1: reduction of the current uncertainty of the impact of aerosol particles on climate by $50 \%$ and quantification of the relationship between anthropogenic aerosol particles and regional air quality; and Objective 2: quantification of the side effects of European air quality directives on global and regional climate, and provide tools for future quantifications for different stakeholders.

The project focuses on the areas of greatest uncertainty and in doing so will identify and quantify the processes and sources governing global and regional aerosol concentrations; quantify the physico-chemical properties of atmospheric aerosols; and quantify the feedback processes that link climate change and atmospheric aerosol concentrations with emphasis on the production and loading of natural aerosols and their precursors.

As part of achieving these objectives, there are two flavours of field study programmes within Europe centering on the following atmospheric supersites: Mace Head (Ireland), Vavihill (Sweden), Melpitz and Hohenpeissenberg (Germany), Hyytiala and Pallas, (Finland), K-Puzta (Hungary), Jungfraujoch (Switzerland), Puy de Dome (France), Cabauw (Netherlands), Finokalia (Greece), Kosetice (Chech Republic) and San Pietro Capofiume (Italy). The first of these activities was a 12-month (over 2008) period of advanced aerosol measurements at all the above stations. The second of these activities was the Intensive Observing Period (15 May 2008-15 June 2008) where all stations are equipped with the most advanced instrumentation available to be deployed at as many stations as possible. In addition, a suite of research aircraft concentrated on various aerosolcloud experiments primarily located at Cabauw, and airborne Lagrangian studies connecting transects between some of the above supersites as the meteorological and transport opportunities arose.

This study reports on the results of the aerosol characterization studies associated with the Mace Head EUCAARI Intensive Observing Period. Mace Head is uniquely located on the interface between the N. E. Atlantic and Europe, thus enabling sampling of both the cleanest air entering into Europe along with some of the most polluted air being exported out of Europe into the North Atlantic. A description of the station, facilities and history of key results can be found in Jennings et al. (2003) and O'Connor et al. (2009).

A wide range of aerosol and meteorological measurements were conducted during the intensive campaign as follows: meteorological vertical structure (microwave profiler and ceilometer); cloud physics and structure (mm radar), aerosol optical depth (precision filter radiometer; aerosol absorption (Multi-Angle Absorption Photometer), aerosol scattering (nephelometer), aerosol microphysics (condensation particle counters and scanning mobility particle sizers), aerosol hygroscopic growth (Hygroscopicity Tandem Differential Mobility Analyser), cloud condensation nuclei, offline aerosol chemistry (impactors with Nuclear Magnetic Resonance and ion-chromatography) and on-line aerosol chemistry (Aerosol Mass Spectrometry).

During the campaign a range of clean marine and polluted continental air mass categories were encountered and the key aerosol properties associated with these particular air masses are documented and reported here. The results from such a range of instrumentation are likely to be of significant interest to both the process-modelling community and the largescale modeling community.

\section{Methods}

\subsection{The Mace Head Atmospheric Research Station}

The Mace Head Atmospheric Research Station is located in Connemara, County Galway on the Atlantic Ocean coastline of Ireland at $53^{\circ} 19^{\prime} 36^{\prime \prime} \mathrm{N}, 9^{\circ} 54^{\prime} 14^{\prime \prime} \mathrm{W}$ and offers a clean sector from $190^{\circ}$ through west to $300^{\circ}$. Meteorological records show that on average, over $60 \%$ of the air masses arrive at the station in the clean sector (Jennings et al., 2003). Air is sampled at $10 \mathrm{~m}$ height from a main air inlet positioned at $80-120 \mathrm{~m}$ from coast line depending on tide (available at: http://www.macehead.org). 


\subsection{Meteorological instrumentation}

Basic meteorological parameters such as wind speed, direction, relative humidity, atmospheric pressure, precipitation, global radiation, UV-radiation are measured at the $10 \mathrm{~m}$ height level, with some duplication at $22 \mathrm{~m}$. Micrometeorological fluxes are also determined at the $22 \mathrm{~m}$ level. To enhance aerosol and cloud observing capabilities a suite of three synergetic remote sensors have been installed at the Mace Head Atmospheric Station and have been operational since May 2008.

Temporal and spatial aerosol mixing and dispersion within the marine boundary layer, along with cloud development and structure are monitored by a Jenoptik CHM15K Lidar ceilometer $(\lambda=1064 \mathrm{~nm})$, a RPG-HATPRO multi-channel microwave profiler, and a MIRA36, $35 \mathrm{GHz}$ K-band Doppler cloud radar. The three instruments together allow synergetic quantification of cloud microphysics (Frisch et al., 1998; Boers et al., 2000, 2006; Brandau et al., 2009); however, microphysical products are still under development and are beyond the scope of this study. In this study, the microwave profiler, through gradients in the specific humidity profiles, and the Lidar-Ceilometer, through the gradients in aerosol backscatter profiles are used to remotely-sense boundary layer structure. Often in this N. E. Atlantic region the boundary layer comprises more than one layer, typically two but sometimes more (Kunz et al., 2002). Terminology is often a problem so here we define the layer nearest the surface, which is typically well mixed, as the surface mixed layer (SML), noting that this layer can deviate from being wellmixed (i.e. neutral stability), and the layer occupying the region below the Free Troposphere inversion as the decoupled residual or convective (DRC) layer. Results are presented for the vertical extent of the SML inversion and the DRC (or Free Troposphere) inversion level.

The ground-based remote sensing instruments for part of the recommended CLOUDNET suite of sensors that could ultimately be used to derive detailed cloud microphysics such as liquid water content, effective radius and cloud droplet number concentration (Illingworth et al., 2007). Although some initial microphysical results are presented at the end of this study, the methods for microphysical retrievals are beyond the scope of this work.

In-situ and remotely-sensed meteorology was complimented by NOAA Hysplit air mass back trajectories and MODIS ocean products such as sea-surface temperature and chlorophyll- $a$ maps.

\subsection{Aerosol microphysics}

The on-line aerosol analysers sampled from a $10 \mathrm{~m}$ height $10 \mathrm{~cm}$ diameter laminar flow community duct with a $50 \%$ size cut at $500 \mathrm{~nm}$ (Kleefeld et al., 2002). Total particle concentrations at sizes larger than 3 and $10 \mathrm{~nm}$ diameter were sampled using a Thermo Systems Inc. (TSI) Condensation
Particle Counter (CPC) 3025 and 3010, respectively. Size distributions were sampled using a TSI nano-Scanning Mobility Particle Sizer (SMPS) between 3 and $20 \mathrm{~nm}$, scanning every $30 \mathrm{~s}$, and a standard SMPS operating 10-min size distribution scans between 20 and $500 \mathrm{~nm}$ (Wang and Flagan, 1990).

The CPC bank is composed of a standard TSI CPC 3025 with a particle diameter size cutoff of $3 \mathrm{~nm}$ and a TSI CPC 3010 with a $10 \mathrm{~nm}$ cutoff diameter. Data acquisition time resolution for the CPC bank was set to $1 \mathrm{~Hz}$. The CPC 3025 was diluted by a factor of $16: 1$ to avoid saturation of the CPC total number concentration in excess of $100000 \mathrm{~cm}^{-3}$ (Yoon et al., 2005). It is possible to detect number concentration of ultrafine particles up to $1.7 \times 10^{6} \mathrm{~cm}^{-3}$ with the aid of this calibrated dilution system.

Aerosol scattering coefficient measurements were performed by a TSI Inc. 3563 3-wavelength integrating nephelometer (Bodhaine et al., 1991; Heintzenberg and Charlson, 1996). This instrument is designed to measured aerosol light scattering coefficient with a sampling frequency of $1 \mathrm{~Hz}$ at 3 wavelengths $(450,550$ and $700 \mathrm{~nm})$ with two ranges of angular integration: $\left(7^{\circ}-170^{\circ}\right)$ to determine the total scattering coefficient sp and $90^{\circ}-170^{\circ}$ for the assessment of hemispheric backscattering. The instrument was regularly calibrated using $\mathrm{CO}_{2}$ and particle free air during the 30-month period of measurements. Moreover, an automatic zero calibration with particle free air was performed every $60 \mathrm{~min}$ for setting the instrument zero. Due to internal heating of the nephelometer, aerosols were sampled at an average relative humidity of $35 \pm 5 \%$.

AOD (Aerosol Optical Depth) measurements at wavelengths centered at $368,412,501$, and $862 \mathrm{~nm}$ were made at 2 min intervals using a Precision Filter Radiometer (PFR) (Wehrli, 2004). The precision of the PFR instrument is estimated to be approximately 0.01 optical depth (McArthur et al., 2003) across all channels. Cloud-screening of the AOD measurements is carried out by implementation of the AERONET cloud-screening algorithm (Smirnov et al., 2000) along with an additional filter, which flags all measurements if the AOD in the infrared channel is greater than 2. The procedures are outlined in Mulcahy et al. (2009).

Aerosol absorption (and Black Carbon mass) was measured using both a McGee Scientific Aethalometer AE-16 and a Multi-Angle Absorption Photometer (MAAP). Cloud condensation nuclei $(\mathrm{CCN})$ concentration was determined using a Droplet Measurements Technology CCN counter (Lance et al., 2006) operated at supersatuations of $0.1 \%$, $0.25 \%, 0.5 \%$ and $1 \%$.

Hygroscopic properties of aerosol were measured using a Hygroscopic Tandem Differential Mobility Analyzer (HTDMA), as described in Nilsson et al. (2009); Liu and Pui 1978; and Rader and McMurry (1986). The determination of particles growth factor (GF) is done by comparison of sizes of particles in their dry and humidified state. A higher GF indicates more hygroscopic particles resulting from a 
higher affinity for water. The typical setup of any TDMA consists of two DMAs: the first DMA selects a monodisperse aerosol size distribution and the second DMA scans through a range of sizes to determine changes in particle size after the particles have been humidified. The Mace Head H-TDMA incorporates a dry DMA $(\mathrm{RH}=40 \%)$, a nafion humidifier, and a second DMA placed in a temperature controlled box for stabilization of the relative humidity. In the humidifier, the aerosol sample is humidified to $90 \%$ relative humidity. GFs are determined for dry size particles of 35, $50,75,110$ and $165 \mathrm{mn}$. Because the raw data obtained with the H-TDMA (i.e the Growth Factor Measured Distribution Function - MDF) is a smoothed and skewed integral image of the real GF probability density function (GF-PDF), an inversion algorithm is used to retrieve the GF-PDF. This allows showing the correct shape of GF-PDF in detail (Gysel et al., 2009). The Mace Head H-TDMA follows the EUSAAR standard installation and accuracy as summarized in Nilsson et al. (2009) where the GFs and GF standard deviations for the 5 operational dry sizes of ammonium sulphate. The GF standard deviation is less than $2 \%$ for all sizes and the GFs for $35,50,75,110,165 \mathrm{~nm}$ particles are 1.62, 1.67, 1.69. 1.71. and 1.73 respectively and were found to be within a growth factor deviation of \pm 0.05 compared to previous recored data (Tang and Munkelwitz, 1994). Unfortunately, as a first deployment of the instrument at Mace Head, the maximum GF range was limited to 2 due to arching within the instrument and consequently, the instrument could not detect higher GFs.

\subsection{Aerosol mass spectrometry}

In recent years aerosol mass spectrometry has become available as a powerful tool for the on-line chemical characterization of individual aerosol particles (Murphy, 2007) or small aerosol ensembles (Canagaratna et al., 2007). Two on-line aerosol mass spectrometers were operated at the measurement site, an ATOFMS (Model 3800-100, TSI, Inc.) and a HR-ToF-AMS (Aerodyne Research, Inc.). The ATOFMS collects bipolar mass spectra of individual aerosol particles. Ambient aerosol is focused into a narrow particle beam for sizes between $100 \mathrm{~nm}$ and $3 \mu \mathrm{m}$. Using a 2-laser velocimeter particle sizes are determined from particle velocity after acceleration into the vacuum. In addition, the light scattered by the particles is used to trigger a pulsed high power desorption and ionization laser $(\lambda=266 \mathrm{~nm}$, about $1 \mathrm{~mJ} /$ pulse) which evaporates and ionizes the particle in the centre of the ion source of a bipolar reflectron ToF-MS. Thus, a positive and negative ion spectrum of a single particle are obtained. The Aerodyne High-Resolution Time-of-Flight Aerosol Mass Spectrometer (HR-ToF-AMS) (Drewnick et al., 2005) focuses aerosol particles in the size range 50$600 \mathrm{~nm}$ quantitatively onto a hot surface $\left(\sim 600^{\circ} \mathrm{C}\right)$ using an aerodynamic lens assembly (Jayne et al., 2000). Smaller and larger particles are also collected with lower efficiency.
Non-refractory particle components flash-evaporate on the hot surface; the evolving vapour is electron impact $(70 \mathrm{eV})$ ionized and the ions are transported into an orthogonal extraction ToF-MS for high-resolution mass analysis. Particle size information is obtained by chopping the particle beam and collecting mass spectra as a function of particle flight time. The instrument provides 5-min averages of mass concentrations of the non-refractory aerosol components as well as species-resolved size distributions. A detailed description of the instrument and its operation is given in Drewnick et al. (2005). The instrument provides quantitative mass loading information on non refractory components using a well characterised series of calibrations and error estimations (Jimenez et al., 2003; Allan et al., 2003b, 2004).

The HR-ToF-AMS (DeCarlo et al., 2006) was deployed in the standard configuration, taking both mass spectrum (MS) and particle time of flight ( $\mathrm{pToF}$ ) data. The AMS was run in "V-mode" with a mass resolution of up to $3000 \mathrm{~m} / \Delta \mathrm{m}$ alternatively with a "W-mode" by using a second reflectron, which increases resolution to $6000 \mathrm{~m} / \Delta \mathrm{m}$ but decreases sensitivity by approximately one order of magnitude. The instruments were calibrated using $300 \mathrm{~nm}$ monodisperse ammonium nitrate particles. Data obtained here were validated by comparing the AMS total mass loading with the ones derived by using the SMPS (by converting volume size distributions into mass size distributions and assumed density of 1.4) and nephelometer data. The analysis of the high resolution AMS data goes beyond the scope of this paper and will be object of future publication. The AMS data shown here give a general overview of the general AMS components (organics, sulphate, ammonium, MSA and nitrate) for different air masses impacting Mace Head during the EUCAARI intensive field study. Calibrations were performed during the campaign, including particle-Time-of-Flight calibration to convert the particle flight times into particle diameters and to determine the instrument background parameters by measurements through a high efficiency particulate air filter (HEPA filter) during the campaign. The unit mass resolution data from the $\mathrm{V}$ mode of the HR-TOF were analyzed using the "fragmentation table" method described by Allan et al. (2004). This separates signals within the mass spectra according to chemical source by performing weighted subtractions and substitutions based on key identification peaks in the form 5 of matrix operators. For error estimation, the model described by Allan et al. (2003b) was applied to the unit mass resolution data, propagated through the matrices. Beside the 4 typical aerosol components (organics, sulphate, ammonium and nitrate), MSA concentrations were also obtained following the same procedure described in Zhorn et al. (2008). After this calculation, MSA no longer contributes to the mass fragments of AMS "sulfate" and "organics".

The ATOFMS collected about 600000 single particle positive and negative mass spectra. The TSI ATOFMS dataset was imported into YAADA (Yet Another ATOFMS Data Analyzer) and single particle mass spectra were grouped with 
Adaptive Resonance Theory neural network, ART-2a (Song et al., 1999). The parameters used for ART-2a in this experiment were: learning rate 0.05 , vigilance factor 0.85 , and iterations 20. Similar clusters obtained by ART-2a were further manually merged (Dall'Osto and Harrison, 2006) so the total number of clusters describing the whole database was reduced to 20. Clusters included for example sea salt, dust, Elemental carbon, biomass, Nitrate-rich and many other particle types.

\subsection{Off-line aerosol chemical analysis}

Aerosol samples for offline chemical analyses were collected deploying an 8-stage Berner low pressure impactor (BI8), equipped with tedlar foils, and a high volume sampler, mounting quartz fiber filters. The BI8 collects particles in eight size fractions between 0.06 and $16 \mu \mathrm{m}$ diameter (cutoffs: $0.06,0.125,0.25,0.50,1.0,2.0,4.0$ and $8.0 \mu \mathrm{m}$ at $50 \%$ efficiency); however, the uppermost stage $(8.0-16.0 \mu \mathrm{m})$ was not analyzed due to the very low collection efficiency of the impactor inlet for these sizes at wind speeds of $5 \mathrm{~m} \mathrm{~s}^{-1}$ and above. The high volume sampler segregates between fine $\left(D_{p}<1.5 \mu \mathrm{m}\right)$ and coarse particles $\left(1.5<D_{p}<0 \mu \mathrm{m}\right)$. Analyses of aerosol inorganic components and water soluble organic carbon (WSOC) were performed on tedlar foils following $\mathrm{mQ}$ water extraction, by $30 \mathrm{~min}$ sonication (Matta et al., 2003). Anions were separated and quantified on a Dionex ICS-2000 ion chromatograph, equipped with IonPac AG11 $2 \times 50 \mathrm{~mm}$ Dionex guard column, IonPac AS11 $2 \times 250 \mathrm{~mm}$ Dionex separation column and ASRS ULTRA II self-regenerating suppressor. This program allows separation of both inorganic cations (sodium, ammonium, potassium, magnesium, calcium) and methyl-, dimethyl-, trimethyl-, ethyl- and diethylammonium. WSOC analyses were performed deploying the instrumental setup described in Rinaldi et al. (2007).

The high volume samples were used for the determination of Total Carbon (TC) and WSOC and for the aerosol organic fraction characterization. WSOC was determined following the above procedure. TC analyses were performed by an Analytik Jena Multi N/C2100 elemental analyzer equipped with a solid furnace module. Inside the instrument furnace, the sample was exposed to a constant temperature of $950{ }^{\circ} \mathrm{C}$ in $100 \% \mathrm{O}_{2}$ and the $\mathrm{TC}$ was determined as the total evolved $\mathrm{CO}_{2}$ by a non-dispersive infrared (NDIR) detector. The aerosol water insoluble organic carbon (WIOC) content was calculated as the difference between TC and WSOC. The ratio WSOC/TC established from high volume samples, and WSOC concentrations from impactor samples were combined to derive the WIOC size distribution. Proton Nuclear Magnetic Resonance (1H NMR) spectroscopy was employed for functional group analysis of WSOC extracted from high volume samples as described in Cavalli et al. (2004). The WSOC was converted to water soluble organic mass (WSOM) using a factor of 1.8 , based on the functional group composition of WSOC. A conversion factor of 1.4 was instead applied to convert WIOC to water insoluble organic mass (WIOM), according to the functional group composition observed by 1H NMR in sea spray organic aerosols (Facchini et al., 2008b). Sea salt and nss$\mathrm{SO}_{4}^{-2}$ aerosol concentrations were calculated using $\mathrm{Na}^{+}$as sea salt tracer and a standard sea salt composition (Seinfeld and Pandis, 1998).

\section{Results}

\subsection{Meteorology: air mass classification and boundary layer structure}

Air Masses: Back trajectories of the air masses arriving at Mace Head were calculated for 00:00 UTC and 12:00 UTC for each day of the campaign, depicting the path taken by the air mass reaching the sampling site over the previous five days. The back trajectories were run using the on-line HYSPLIT model developed by the National Oceanic and Atmospheric Administration (NOAA). We present an overall meteorological air mass summary of the EUCAARI campaign, categorising it into five synoptic period types. Figure 1 illustrates typical examples of the five back trajectory types for selected days: day 24th May (Continental European denoted by $c P$ in strict meteorological terms ), 31st May (Continental-Marine, $c m P$ ), 7th June (Polar Marine, $m P$ ), 9th June (Tropical Marine, $m T$ ) and 12th June (Arctic Marine, $m A$ ). They are representative of the different periods listed in Table 1. The local meteorological conditions (wind speed, direction, relative humidity and temperature) associated with these periods are listed in Table 2. Characteristics associated with the different air mass categories are summarized as follows:

(European) Continental Polar $(c P)$ : This continental outflow period lasted from about 16 May 08 00:00 to 29 May 09 12:00 (13.5 days) and was characterized by sunny and warm conditions. Air masses originated most of the time from the East, advecting out from central Europe, through the UK and Ireland. Some days also had a northern European component to them. The average wind speed $\left(13.1 \pm 5.2 \mathrm{~m} \mathrm{~s}^{-1}\right)$ was the strongest of the five periods, and wind direction confirmed the strong average Easterly component $\left(108 \pm 59^{\circ}\right)$. The values of wind speed and direction are given \pm one standard deviation. In all subsequent values of parameters reported \pm a range, the range corresponds to one standard deviation.

Continental-Marine Polar ( $\mathrm{cmP})$ : This modified continental/marine period lasted for about 4.5 days from 29 May 08 12:00 to 03 June 08 00:00. The air stagnated as a pressure gradually strengthened and centered over Mace Head and anti-cyclonic conditions were observed for most of the time during this period. The lowest wind speed $\left(6.4 \pm 3.8 \mathrm{~m} \mathrm{~s}^{-1}\right.$; Table 1) of the five periods occurred during this period. 


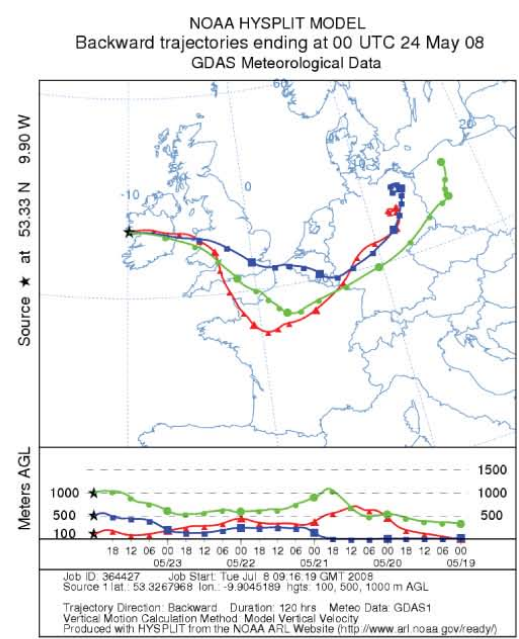

(a) $c P$

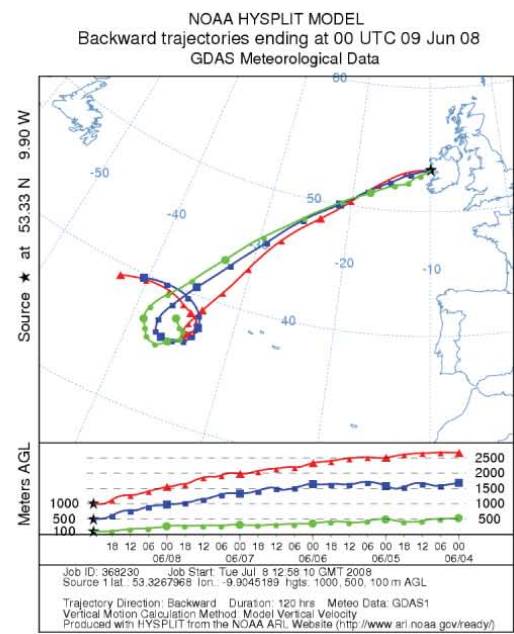

(d) $m T$

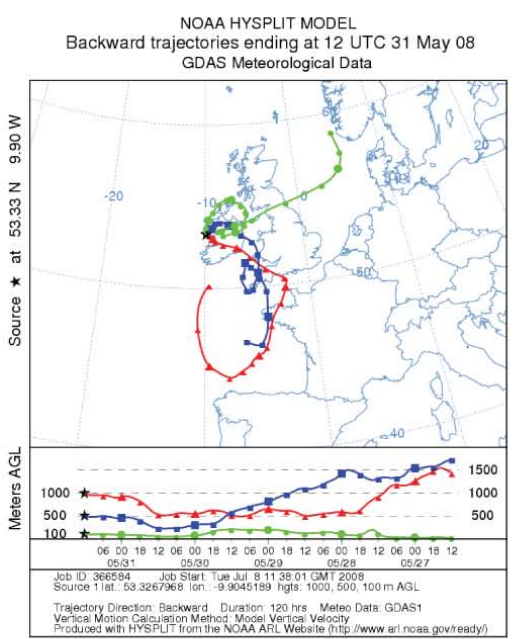

(b) $\mathrm{cmP}$

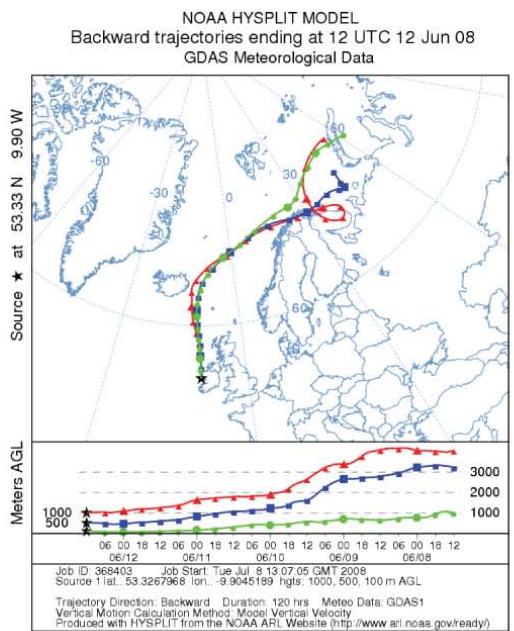

(e) $m A$

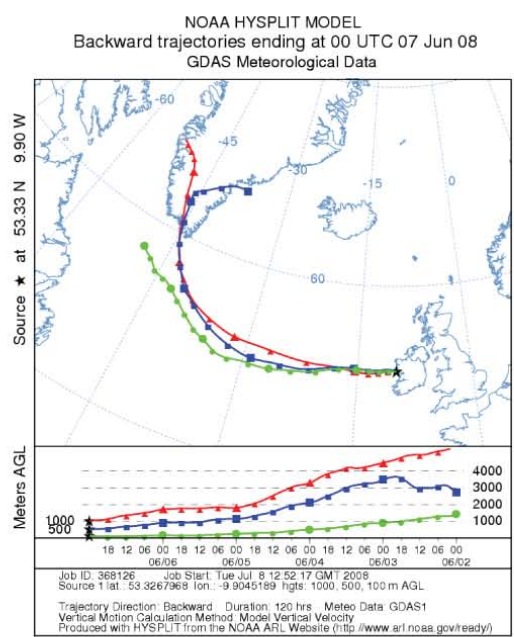

(c) $m P$

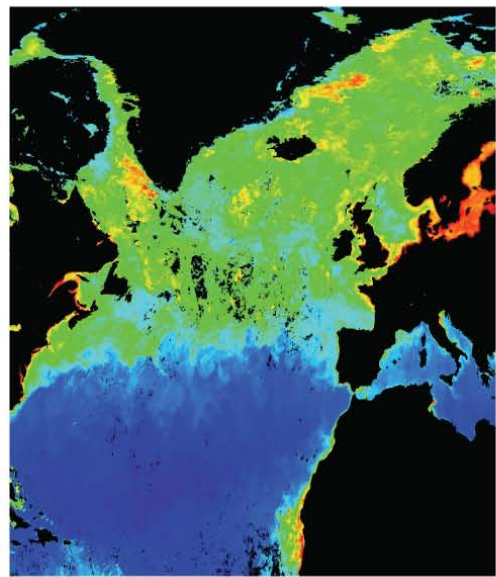

(f) MODIS Chlorophyll-a

Fig. 1. Typical air mass back trajectories for (a) $c P$, (b) $c m P$ (c) $m P$, (d) $m T$, (e) $m A$ air masses and (f) MODIS chlorophyll- $a$ maps.

Table 1. Summary of the five different periods.

\begin{tabular}{lcl}
\hline Period & Number of days & Air masses \\
\hline 16 May 08 00:00-29 May 08 12:00 & 13.5 & Continental Europe $(\mathrm{cP})$ \\
29 May 08 12:00-03 June 08 00:00 & 4.5 & Continental-Marine $(\mathrm{cmP})$ \\
03 June 08 12:00-08 June 08 00:00 & 4.5 & Polar Marine $(\mathrm{mP})$ \\
08 June 08 00:00-10 June 08 00:00 & 2.0 & Tropical Marine $(\mathrm{mT})$ \\
10 June 08 12:00-15 June 08 00:00 & 4.5 & Arctic Marine $(\mathrm{mA})$ \\
\hline
\end{tabular}


Table 2. Meteorologiacal conditions.

\begin{tabular}{lllll}
\hline PERIOD & WS $[\mathrm{m} / \mathrm{s}]$ & $\mathrm{WD}\left[^{\circ}\right]$ & Temp $\left[^{\circ}\right]$ & RH [\%] \\
\hline Continental Europe $(c P)$ & $13.1 \pm 5.2$ & $108 \pm 59$ & $12.4 \mathrm{~m} \pm 1.7$ & $79.9 \pm 11.2$ \\
Continental-Marine $(\mathrm{cm} P)$ & $6.4 \pm 3.8$ & $185 \pm 92$ & $14.5 \pm 1.7$ & $89.6 \pm 7.2$ \\
Polar Marine $(m P)$ & $12.6 \pm 5.0$ & $242 \pm 44$ & $12.8 \pm 1.3$ & $77.1 \pm 9.5$ \\
Tropical Marine $(m T)$ & $8.58 \pm 4.0$ & $244 \pm 31$ & $14.5 \pm 0.8$ & $91.9 \pm 5.4$ \\
Arctic Marine $(m A)$ & $10.4 \pm 2.7$ & $300 \pm 39$ & $13.1 \pm 1.4$ & $86.2 \pm 10.4$ \\
\hline
\end{tabular}

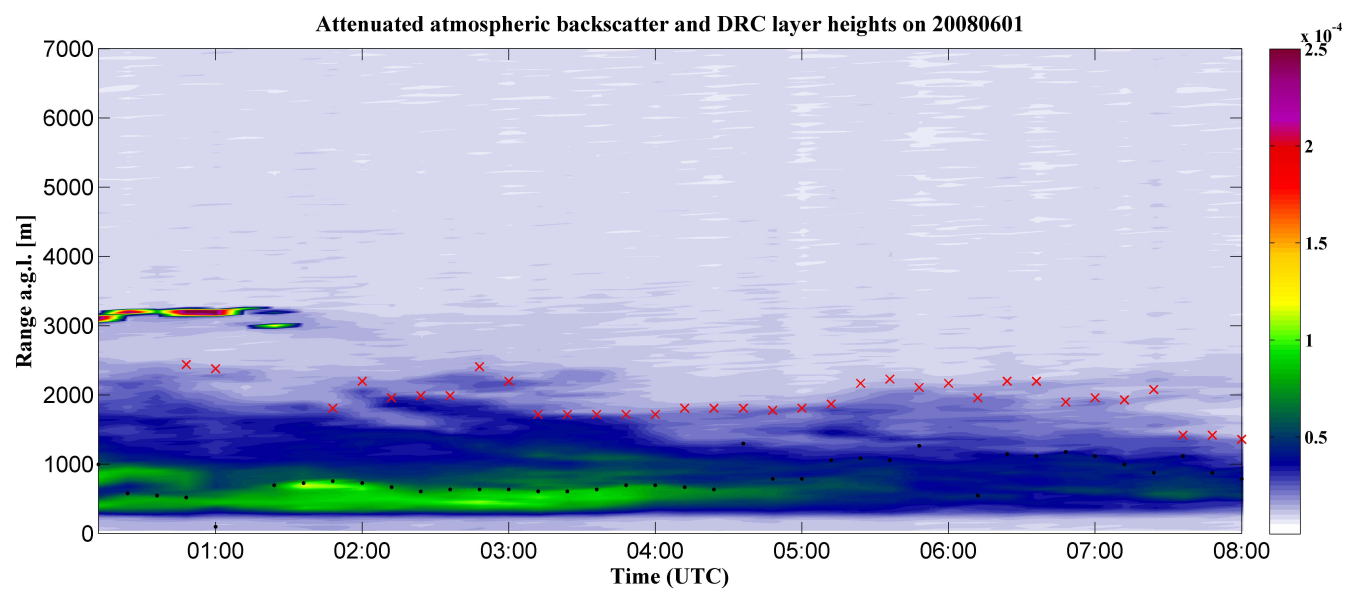

Fig. 2. Decoupled boundary layer on JD153 (01/06/2008). Black points mark the top of the SML while the red crosses mark the top of the overlying DRC layer (the main boundary layer - free troposphere inversion. It should be noted that the lowest $200 \mathrm{~m}$ represents the region of incomplete overlap between the receiver field of view and the transmitted laser beam and should be disregarded as unusable data.

Marine Polar ( $m P$ ): From 03 June 08 00:00 to 08 June 09 00:00, this polar marine period (4.5 days) was subjected to air masses emerging from polar regions around southern Greenland and advecting south-east over the North Atlantic and into Europe (advecting through).

Marine Tropical $(m T)$ : This tropical maritime, or perhaps more accurately sub-tropical maritime, period lasted from about 08 June 08 00:00 to 10 June 09 00:00 (about 2 days) and was characterized bye 5-day back trajectories indicating an origin from the Azores high-pressure region. Whilst the average wind direction is similar to period $3\left(242 \pm 44^{\circ}\right.$ and $244 \pm 31^{\circ}$ ), the temperature and the RH of period 4 (Table 2) are both higher than period 3 (polar marine) supporting the warmer tropical or sub-tropical conditions.

Arctic Marine $(m A)$ : This Arctic marine period lasted for 4.5 days from 10 June 08 12:00 to 15 June 08 00:00 with air coming mainly form the north Scandanavian Arctic regions, advecting out over the Atlantic region towards Iceland before advecting southwards to Mace Head (Table 2, WD $300 \pm 39^{\circ}$ supporting the Northerly wind conditions).

Also shown in Fig. 1 is the MODIS chlorophyll- $a$ average mass concentration distribution over the period. It can be seen that peak concentrations occur to the north waters and minimum to the south west approaches.

Boundary layer structure: characteristic of this region, with warm waters, the marine boundary layer is typically 2-layered with a surface mixed layer (SML) and a decoupled residual or convective layer (DRC), above which is the Free Troposphere (Kunz et al., 2002). An example of decoupled marine boundary layer, as detected by the ceilometer (aerosol backscatter gradient) is shown in Fig. 2 (case 01 June 2008) where the SML is sharply decoupled from the overlying DRC layer. For all periods, by air mass category, the boundary layer structure is illustrated through a combination of specific humidity profiles from the radiometer and, superimposed in Fig. 3, the SML and DRC layer heights derived from the ceilometer. Good agreement is seen for most overlapping periods using the two approaches under most air masses (noting that because of thick stratocumulus cover in the $m T$ case, the top of the boundary layer (or cloud top) is not detected with the ceilometer.

From the ceilometer data, the daily averaged SML and DRC depths for all cases through the studied period are shown in Fig. 4 where the boundary layer structure exhibits 

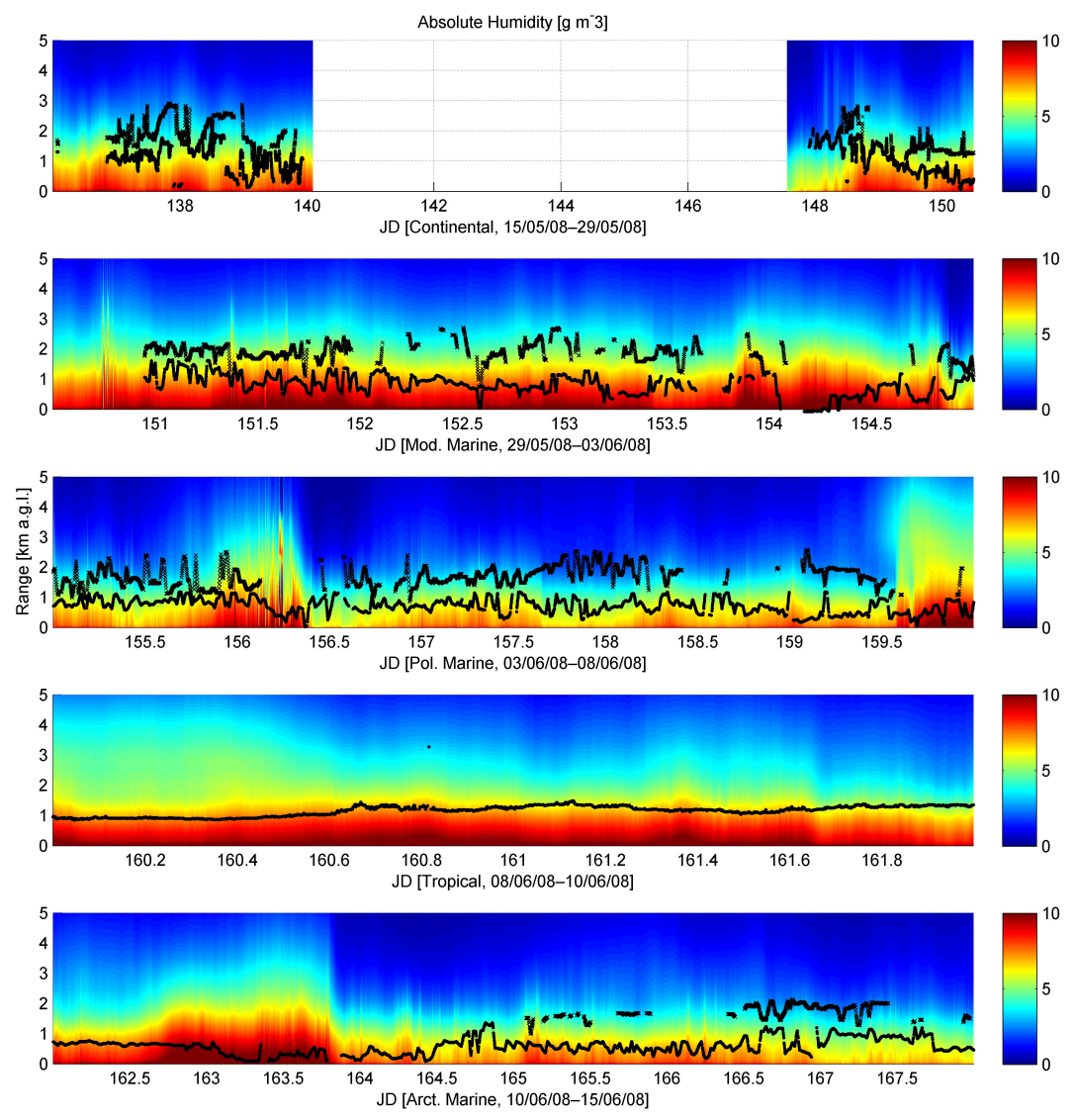

Fig. 3. Boundary Layer stratification observed from the HATPRO microwave profiler absolute humidity product with Lidar-Ceilometer derived layer structure superimposed on the humidity contour plot. The y-axis is kilometers a.g.l. where ground level is approximately $15 \mathrm{~m}$ a.s.l. The $\mathrm{x}$-axis is Julian Day (JD).

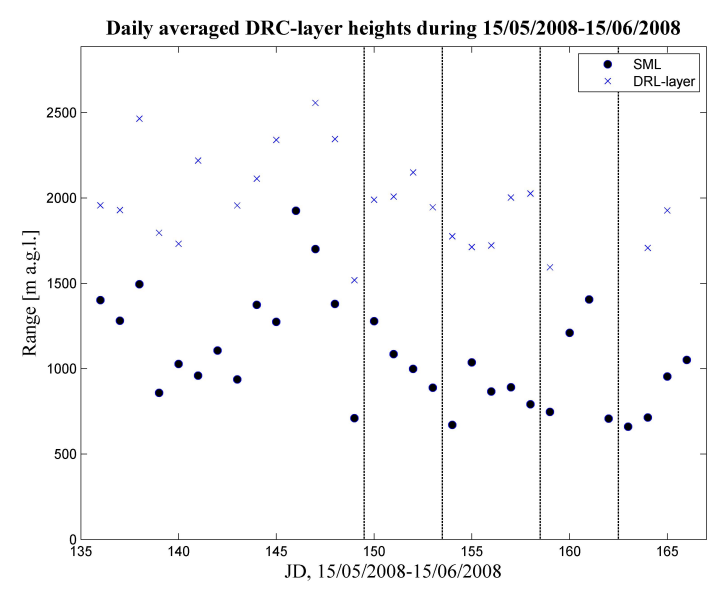

Fig. 4. Boundary Layer (residual and convective) height and Surface Mixed Layer height from 15 May 2008 at Mace Head. The y-axis is meters a.g.l. where ground level is approximately $15 \mathrm{~m}$ a.s.l. The $\mathrm{x}$-axis is Julian Day (JD). The vertical lines separate the different air masses: from left to right, these correspond to $c P, \mathrm{~cm} P$, $m P, m T, m A$, respectively. a high degree of variability throughout the period as illustrated for the higher temporal resolution data in Fig. 3. The daily average height of the SML layer varied from $500 \mathrm{~m}$ to almost $2000 \mathrm{~m}$ but was more typically in the range of $700 \mathrm{~m}$ to $1500 \mathrm{~m}$. The overlying DRC, or main Free Troposphere inversion layer, has a minimum of $1500 \mathrm{~m}$ and maximum of $2500 \mathrm{~m}$. Both layers were typically highest for the $c P$ air mass with the highest wind speeds and lowest for the $m P, m T$ and $m A$ air masses. Surprisingly there was no notable difference between the latter three types. Further, in all air masses no significant diurnal variation was observed as is typical of $c P$ air masses (e.g. Nilsson et al., 2001). Further analyses where the daily averages over each period are analysed illustrates differences between $m P, m T$ and $m A$ are more evident with decreasing average daily depth development following the order $c P, c m P, m P, m A$, and $m T$.

\subsection{Aerosol concentration and size distributions}

The frequency distribution of 2-min average total particle concentrations $(D>3 \mathrm{~nm})$, shown in Fig. 5, exhibits four modes in log-concentration space. One mode 


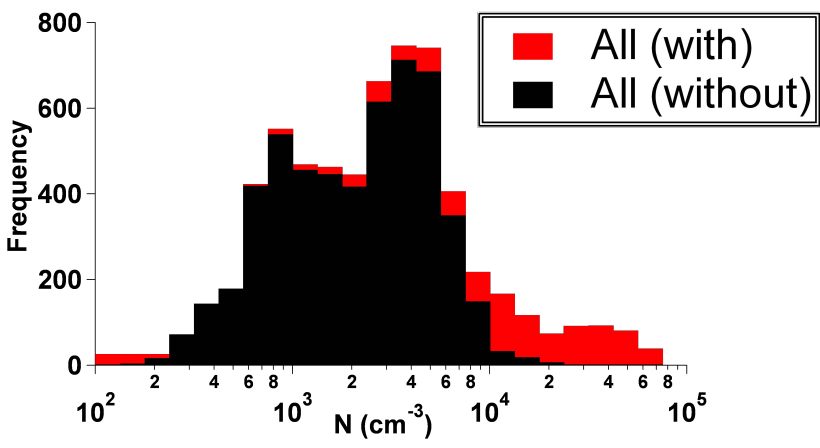

Fig. 5. Total aerosol/condensation nuclei concentrations $(d>3 \mathrm{~nm})$ for all data including nucleation events (red) and all data excluding nucleation events (black). The particle concentration data is averaged over $2 \mathrm{~min}$.

exists at concentrations of $400-600 \mathrm{~cm}^{-3}$, reflecting the background marine number concentration; a second mode at $800-900 \mathrm{~cm}^{-3}$ reflecting either modified marine air and/or clean marine air following open ocean nucleation events (discussed later), a third mode at $3000-5000 \mathrm{~cm}^{-3}$. exists reflecting the continental input and a fourth more centered on $30000-40000 \mathrm{~cm}^{-3}$ exists, reflecting the coastal nucleation mode (O'Dowd et al., 1998).

A surface contour plot of the observed aerosol size distributions (range $3.5 \mathrm{~nm}-500 \mathrm{~nm}$ ) throughout the period is shown in Fig. 6. Overlaid on the plot are the time periods over which the different air massed occurred and when the nucleation events were detected. Clearly, for the first two periods $(c P$ and $c m P$ ) of the campaign, a significantly higher loading of particle number concentration can be seen in the accumulation mode. However, Mace Head is subjected to significant coastal, tidal-driven, nucleation events (O'Dowd et al., 1998, 1999, 2002; Grenfell et al., 1999) which influence the particle number concentrations. During the intensive field study, 28 nucleation events were detected by the nano-SMPS/SMPS system. For the main air mass characteristic data presented in this study, the data were filtered to remove periods where nucleation events occurred, resulting in total data coverage of $78 \%$ for non nucleation periods, and $22 \%$ of the nucleation periods. Moreover, there were few so called special events like a biomass burning on 5th June for $2 \mathrm{~h}$ (05:00-07:00) that were not considered in the analysis.

Average size distributions for non-nucleation periods in the different air masses are presented in Fig. 7a. Both the $c P$ and $c m P$ size distributions exhibited mono-modality with a modal diameter of $60 \mathrm{~nm}$ in both cases and respective average concentrations of $3261 \mathrm{~cm}^{-3}$ and $3044 \mathrm{~cm}^{-3}$, although in the $c P$ case, evidence of a less significant accumulation mode in the range of $200 \mathrm{~nm}-300 \mathrm{~nm}$ is evident. The $m T$ and $m A$ cases are bimodal with an accumulation mode located at $250 \mathrm{~nm}$ for $m A$ and $300 \mathrm{~nm}$ for $m T$ cases. Both air masses posed an Aitken mode with modal diameter of $50 \mathrm{~nm}$ for $m T$ air and $60 \mathrm{~nm}$ for $m A$ air. Average total particle concentrations were $625 \mathrm{~cm}^{-3}$ and $795 \mathrm{~cm}^{-3}$ for $m T$ and $m A$ air, respectively.

For $m P$ air masses, three modes were observed: an accumulation mode at $200 \mathrm{~nm}$, an Aitken mode at $35 \mathrm{~nm}$ and a nucleation mode (as distinct from coastal nucleation) at 15$20 \mathrm{~nm}$. The number concentration associated with these $m T$ air masses was $625 \mathrm{~cm}^{-3}$, representing the lowest of all 5 periods. For $m P$ air, concentrations of $1025 \mathrm{~cm}^{-3}$ were highest of the three marine cases and elevated due to the noncoastal nucleation mode. In summary, 3 size distribution groups in non-nucleation periods in the different air masses were found: (1) monomodality at about $60 \mathrm{~nm}$ for $c P$ and $\mathrm{cmP}$ air masses (2) bimodality at about 50-60 nm and 250$300 \mathrm{~nm}$ for $m T$ and $m A$ air masses; and trimodality at 15$20 \mathrm{~nm}, 35 \mathrm{~nm}$ and $200 \mathrm{~nm}$ for $m P$ air masses.

Previous studies conduced at Mace Head found typically, the sub-micron marine size distribution possessed a bi-modal shape, with an accumulation mode centered at $200 \mathrm{~nm}$ and a fine mode at $40 \mathrm{~nm}$ (O Dowd et al., 2001). The bi-modal nature of the sub-micron mode is indicative of a cloud-residual accumulation mode produced by the in-cloud growth of activated fine mode particles (Hoppel et al., 1994). O'Dowd et al. (2001) and Coe et al. (2006) reported that during anticyclonic periods and conditions of continental outflow Aitken and accumulation mode were enhanced by a factor of $5 \mathrm{com}$ pared to the marine sector, whilst coarse mode particles were enhanced during westerly polar marine conditions.

The aerosol size distributions when coastal nucleation was occurring under the five different periods are shown in Fig. 7b. The stagnant conditions of period 2 $(\mathrm{cmP})$ led to highest period-average number concentration $\left(N=27025 \mathrm{~cm}^{-3}\right)$. O'Dowd et al. (2002) attributed the mode extending to slightly larger sizes in polluted conditions ( $c P$ over the $\mathrm{cmP}$ case) to the inter-tidal source of the precursors being further from the measuring site and reflecting longer particle growth times before detection, Periods dominated by $m T$ air masses presented a different average aerosol size distribution, with the lowest particle number concentrations $\left(3054 \mathrm{~cm}^{-3}\right.$, respectively). Along with the typical Aitken mode and accumulation mode at $70 \mathrm{~nm}$ and $300 \mathrm{~nm}$, respectively, the mode at $6 \mathrm{~nm}$ due to local nucleation can also be seen. The $m A$ and $m P$ periods posses more ultrafine or nucleation modes structure representing multiple source regions contribution to the coastal nucleation events; however, for $\mathrm{mP}$ air, these additional modes are likely to be also influenced by off-shore particle formation events. 


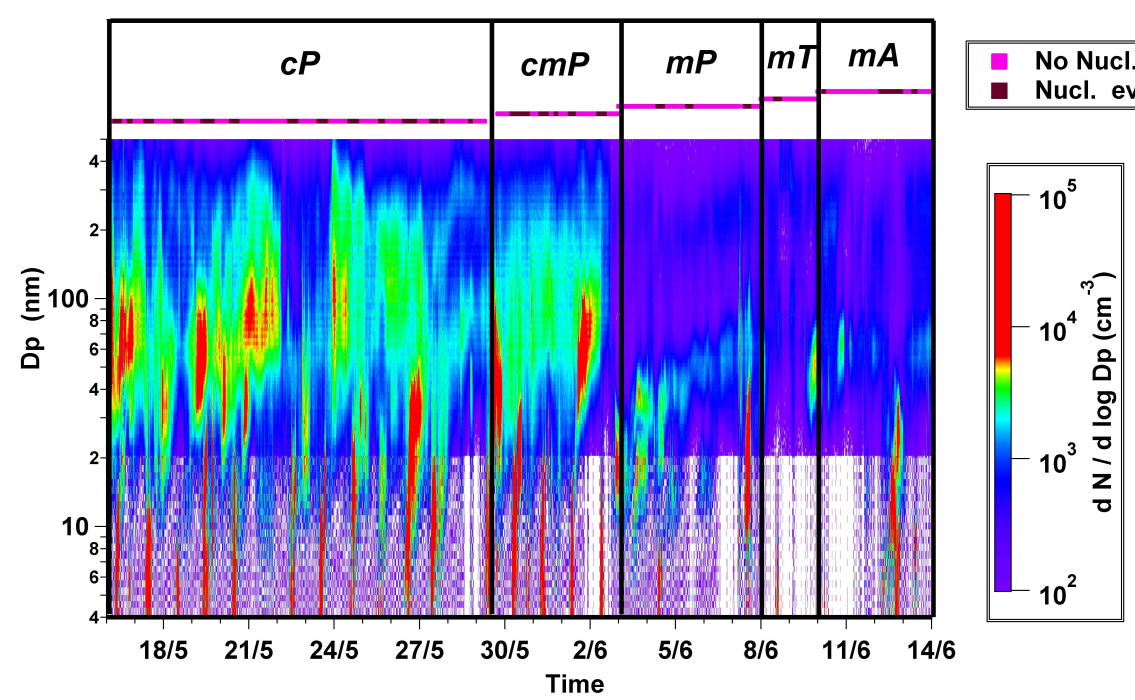

Fig. 6. Aerosol size distributions from the combined nano-SMPS and SMPS. Air mass types are highlighted as are nucleation and nonnucleation events.

(a)

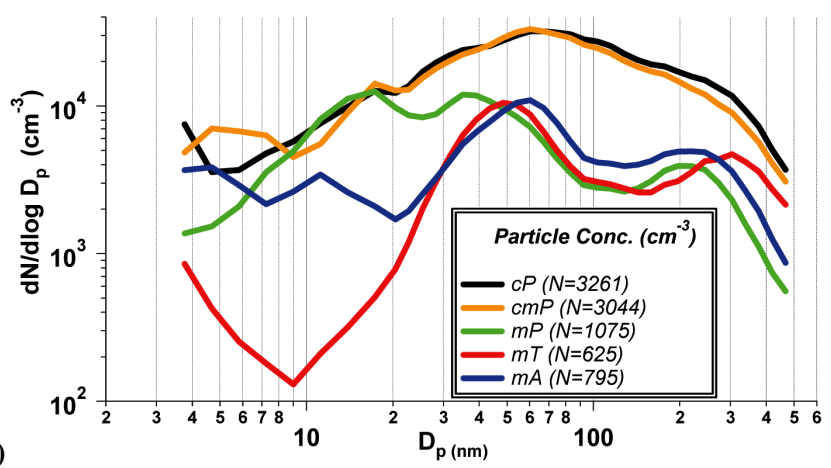

(b)

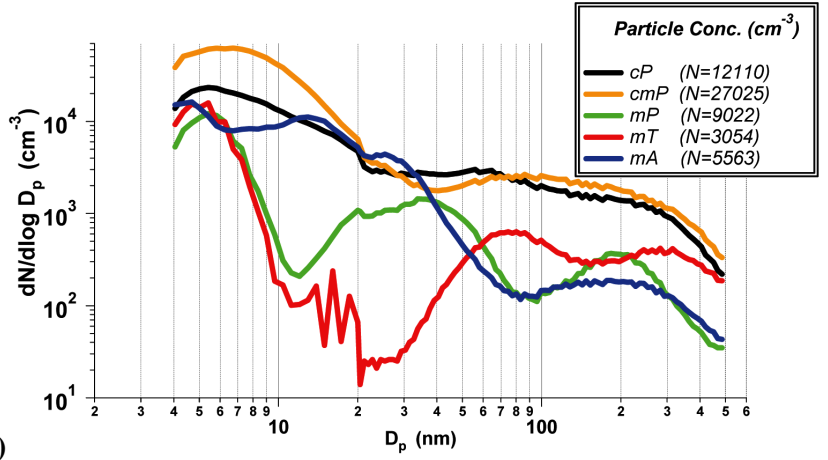

Fig. 7. (a) aerosol size distributions averaged by air mass and excluding coastal nucleation events and (b) aerosol size distributions averaged by air mass during nucleation events. $N$ in the key represents total particle concentration per $\mathrm{cm}^{-3}$ from sizes between $4-500 \mathrm{~nm}$.

\subsection{Aerosol chemical composition}

\subsubsection{On-line aerosol chemical composition}

\section{Black Carbon concentrations (MAAP and Aethalometer)}

As shown in Fig. 8, the black carbon data exhibited two distinct concentration groups, one representing period 1 and period 2 with concentrations above $300 \mathrm{ng} \mathrm{m}^{-3}(389 \pm 202$ and $328 \pm 115$, respectively); and the other representing the last 3 periods with much lower concentrations below $50 \mathrm{ng} \mathrm{m}^{-3}$ $\left(25 \pm 13,45 \pm 27,17 \pm 14 \mathrm{ng} \mathrm{m}^{-3}\right.$ for period 3, 4 and 5 respectively), typical of clean N. E. Atlantic black carbon loadings (O'Dowd et al., 1993). The Aethalometer showed a similar trend, but for the polluted period (periods 1 and 2) it underestimated the MAAP concentration while in clean air masses (periods 3, 4 and 5) it overestimated the MAAP concentrations. These issues are discussed in more detail by Jennings et al. (2008) and were attributed to the impact of sea salt and relative humidity on the performance of AE-16; however, a conclusive explanation of the two absorption instruments remains to be addressed.

\section{PM$_{2.5}$ mass and AMS (size resolved mass spectrometry) composition and mass}

Table 3 shows the average $\mathrm{PM}_{2.5}$ concentrations for the 5 different periods, including average mass concentrations obtained from the AMS for nitrate, sulphate, MSA, organics and ammonium. AMS chemical concentrations are illustrated in Fig. 9. The highest $\mathrm{PM}_{2.5}$ mass loadings were encountered during the polluted periods, whilst the lowest 
Table 3. PM mass and AMS derived sulphate, organic, MSA, nitrate and ammonium mass.

\begin{tabular}{lcccccc}
\hline $\mathrm{PM}_{2.5}$ & $\begin{array}{c}\text { TEOM } \\
{\left[\mu \mathrm{m}^{-3}\right]}\end{array}$ & $\begin{array}{c}\text { AMS } \\
\text { organics }\end{array}$ & $\begin{array}{c}\text { AMS } \\
\text { nitrate }\end{array}$ & $\begin{array}{c}\text { AMS } \\
\text { sulphate }\end{array}$ & $\begin{array}{c}\text { AMS } \\
\text { MSA }\end{array}$ & $\begin{array}{c}\text { AMS } \\
\text { ammonium }\end{array}$ \\
\hline $\begin{array}{l}\text { Continental } \\
\text { Europe }(c P)\end{array}$ & $12.4 \pm 11.1$ & $1.42 \pm 0.35$ & $0.64 \pm 0.16$ & $1.31 \pm 0.33$ & $0.10 \pm 0.02$ & $0.70 \pm 0.18$ \\
$\begin{array}{l}\text { Continental- } \\
\text { Marine }(\mathrm{cm} P)\end{array}$ & $10.3 \pm 7.2$ & $1.75 \pm 0.44$ & $0.26 \pm 0.07$ & $1.15 \pm 0.29$ & $0.05 \pm 0.01$ & $0.48 \pm 0.12$ \\
$\begin{array}{l}\text { Polar } \\
\text { Marine }(m P)\end{array}$ & $8.6 \pm 6.8$ & $0.11 \pm 0.03$ & $0.04 \pm 0.01$ & $0.67 \pm 0.17$ & $0.13 \pm 0.03$ & $0.08 \pm 0.02$ \\
$\begin{array}{l}\text { Tropical } \\
\text { Marine }(m T)\end{array}$ & $8.7 \pm 5.2$ & $0.17 \pm 0.04$ & $0.06 \pm 0.02$ & $1.81 \pm 0.45$ & $0.28 \pm 0.07$ & $0.24 \pm 0.06$ \\
$\begin{array}{l}\text { Arctic } \\
\text { Marine }(m A)\end{array}$ & $7.1 \pm 6.5$ & $0.02 \pm 0.01$ & $0.04 \pm 0.01$ & $0.93 \pm 0.23$ & $0.16 \pm 0.04$ & $0.10 \pm 0.03$ \\
\hline
\end{tabular}

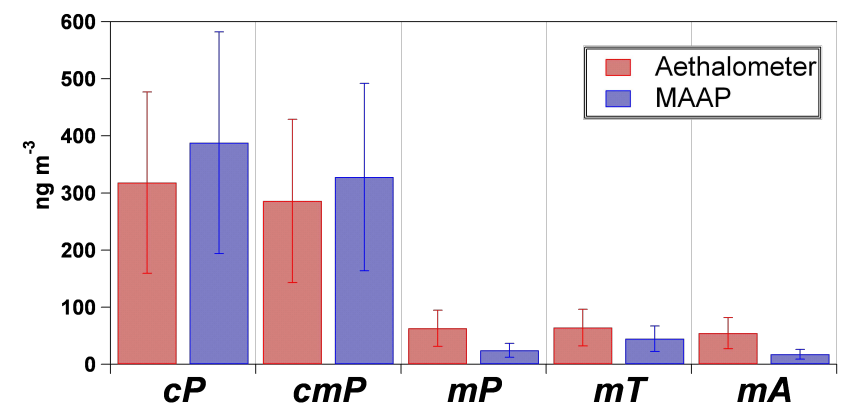

Fig. 8. Aerosol black carbon mass derived from the Aethalometer A-16 and the the MAAP.

during the $m A$ period. Although the AMS total mass loading were the lowest for the $m P$ period, this was not reflected in the $\mathrm{PM}_{2.5}$ loading and it is thought to be due to the higher sea salt contribution during the $m P$ period. Nitrate mass loadings were higher for the polluted periods under $c P$ and $c m P$ air masses with $0.3 \pm 0.5 \mu \mathrm{g} \mathrm{m}^{-3}$ and $0.12 \pm 0.06 \mu \mathrm{g} \mathrm{m}^{-3}$, respectively; whilst for the other 3 periods it was found to be below $0.005 \mu \mathrm{g} \mathrm{m}^{-3}$. Sulphate was found to be the dominant species detected with the AMS during the $m P, m T$ and $m A$ periods, with concentrations of $0.34 \pm 0.2 \mu \mathrm{g} \mathrm{m}^{-3}$, $0.93 \pm 0.45 \mu \mathrm{g} \mathrm{m}^{-3}$ and $0.47 \pm 0.3 \mu \mathrm{g} \mathrm{m}^{-3}$, respectively. In contrast, during $c P$ and $c m P$ periods, sulphate was the second most abundant species after organics with average concentration of $0.67 \pm 0.31 \mu \mathrm{g} \mathrm{m}^{-3}$ and $0.58 \pm 0.29 \mu \mathrm{g} \mathrm{m}^{-3}$, respectively. Regarding the AMS ammonium average concentration, when air masses were anthropogenically-influenced there was complete aerosol neutralization. However, during clean marine periods ( 3,4 and 5) concentrations of ammonium were significantly smaller than the sulphate concentrations (see Table 3). The organic AMS average mass concentration was found to be $0.74 \pm 0.44 \mu \mathrm{g} \mathrm{m}^{-3}$, with the highest concentrations $\left(0.89 \pm 0.4 \mu \mathrm{g} \mathrm{m}^{-3}\right)$ occurring for the $\mathrm{cmP}$

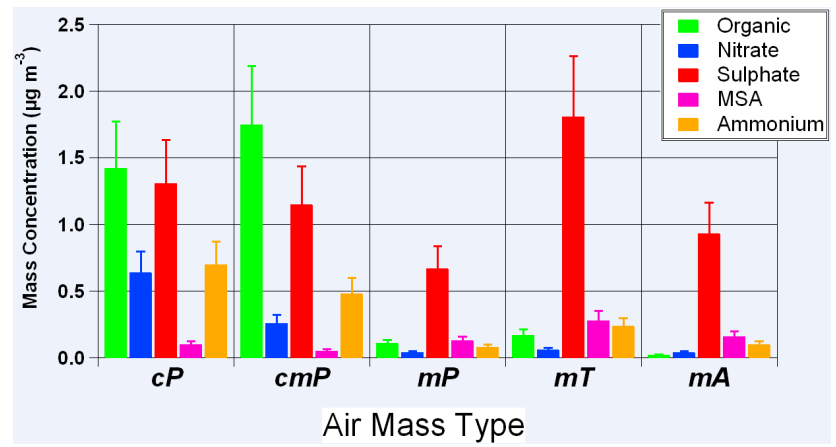

Fig. 9. AMS-derived organic, nitrate, sulphate, MSA, and ammonium mass as a function of air mass.

period. The ratio of sulphate/organic mass for the $\mathrm{cm} P$ period was also found to be higher than the $c P$ period (1.5 vs. 1.1). The significant diversity in the average chemical mass spectra observed during the 5 different periods will be the subject of more detailed investigations in future studies where a detailed analysis from the high resolution ToF-AMS mass spectrum will be presented.

The size distributions for the four generic chemical components (sulphates, organics, nitrate, ammonium) for the 5 different periods obtained from the AMS are presented in Fig. 10. Some consideration must be kept in mind for the average size-resolved AMS mass loading for total organic and sulphate. Whilst Fig. 9 shows a fifth component (MSA) obtained by the HR-ToF-AMS data analysis, the average sizeresolved AMS mass loadings are provided at unit mass resolution and not at high resolution as no current tools are available to generate size-resolved AMS mass loading at high resolution masses. Consequently, the MSA component is split broadly between the organic fraction $(67 \%)$ and the sulphate fraction $(28 \%)$ of the signal (F. Drewnick, personal communication, 2009). 


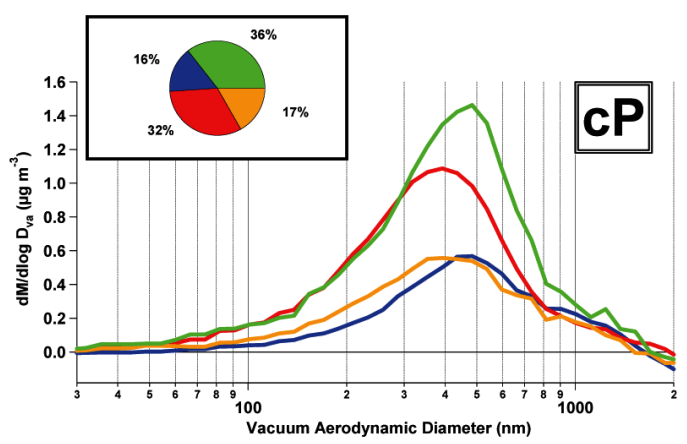

(a)

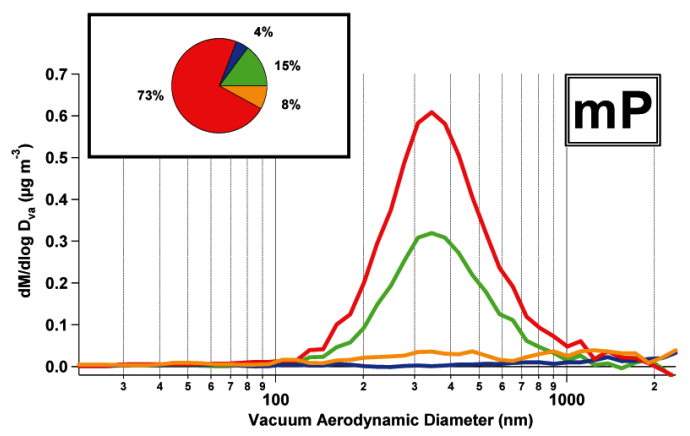

(c)

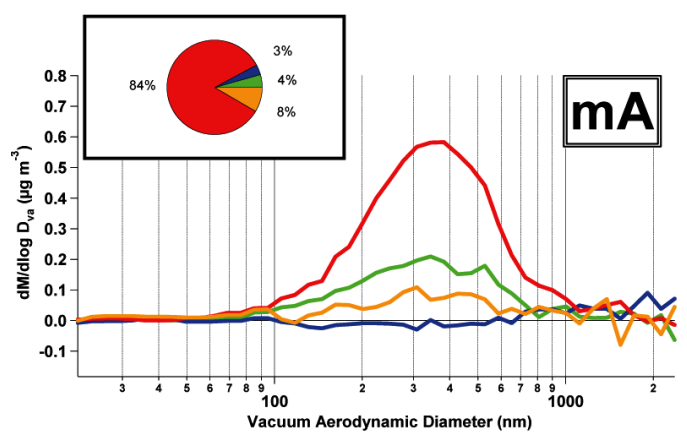

(e)

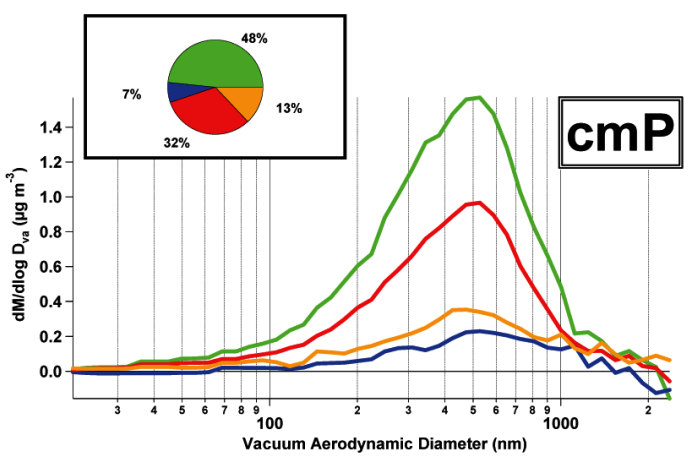

(b)

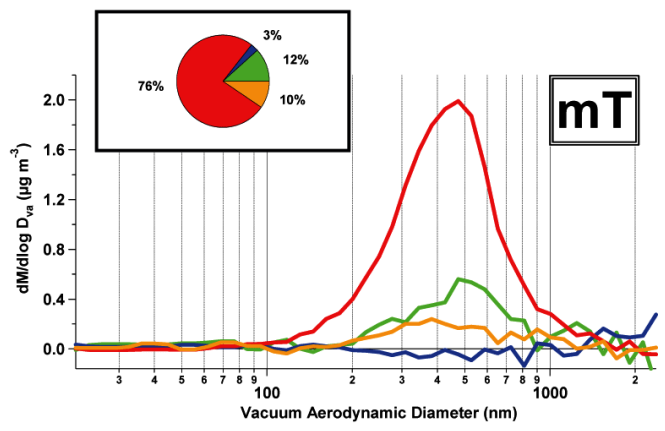

(d)

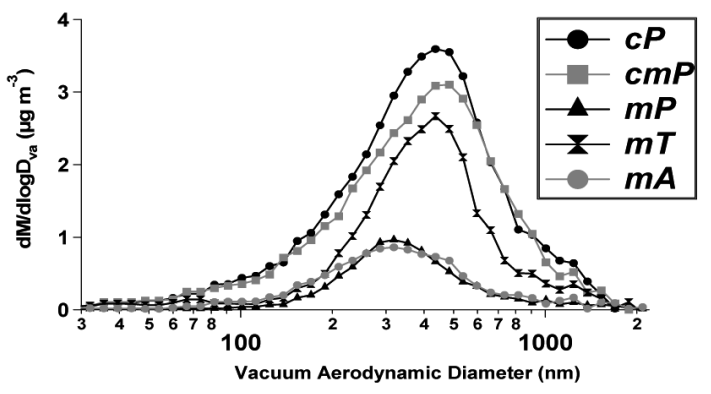

(f)

Fig. 10. (a) $c P$ chemical size distributions (b) $c m P$ chemical size distributions (c) $m P$ chemical sizedistributions (d) $m T$ chemical size distributions (e) $m A$ chemical distributions (f) integrated mass size distributions per air mass. (note the difference is the y-scale of total concentration for different periods.)

The size distributions for the $c P$ and the $c m P$ periods are quite similar in shape for the relative contributions of each chemical species, with an accumulation mass mode distributed between 400 and $500 \mathrm{~nm}$ vacuum aerodynamic diameter. However, the $\mathrm{cmP}$ presented a higher organic mass loading with a shoulder shifted towards smaller particle sizes.
An accumulation mass size distribution at about $500 \mathrm{~nm}$ was also attributed to the $m T$ period, but for $m P$ and $m A$ periods, this was found to peak at smaller diameters at about $300 \mathrm{~nm}$. The sulphate average size distributions for the $m P$ period present a much broader width than the $m A$ period. 


\section{ATOFMS (single particle mass spectrometry)}

20 ATOFMS clusters were obtained by applying ART-2a algorithm to the ATOFMS dataset. Some of the clusters presented very sharp temporal trends, including biomass events and nucleation processes and are not discussed here. The aim of this section is to present a general overview of the mixing state of different aerosol particle types under different air masses. The main particle type represented about $50 \%$ of the population and it was found to be rich in sodium, potassium and sulphate. The ATOFMS is very sensitive to alkali metal cations (Gross et al., 2000) and since sodium and potassium are present in large abundance in sea salt particles, it is not surprising that these are the only peaks visible in some spectra. It should be noted that this particle type internally mixed with alkali metal cations and sulphate but with no nitrate is only typically seen by the ATOFMS deployed in remote marine sites (Furutani et al., 2008). Nitrate-rich particles were found to be associated with periods $c P$ and $c m P$. This particle type was internally mixed with $\mathrm{Na}, \mathrm{K}, \mathrm{OC}$ and EC. The ATOFMS mass spectra of this particle type transported from continental Europe was found to be almost identical to particle types previously associated with long range transport of aerosol arriving in the bigger close British Isle (Dall'Osto et al., 2008, 2009). Within the $c P$ air mass period, some air masses arriving at Mace Head had travelled across mainland Europe and the UK. During our study we found two main trends: anthropogenic influenced aerosol which passed throughout France and Spain was rich in OC and sulphate, whilst aerosol which passed mainly throughout England and the north part of Europe was enriched in K, EC and nitrate. During the $m P$ and $m A$ periods, sub micron particles detected with the ATOFMS were found to be mainly internally mixed with $\mathrm{K}$ and $\mathrm{OC}$, suggesting sea salt particles containing a fraction of organic material.

Two types of clusters associated with sea salt particles were found, named pure sea salt and aged sea salt, representing $14 \%$ and $2.2 \%$ of the ATOFMS particles classified, respectively. Pure sea salt particles were detected only during the last 3 periods ( $m P, m T$ and $m A$ ) air masses, whilst aged sea salt particles were encountered during the first two weeks of the EUCAARI intensive campaign $(c P$ and $c m P$ ) presented. In the ATOFMS positive ion spectra of pure sea salt particle type, peaks were present for $\mathrm{m} / z 23[\mathrm{Na}]^{+}, \mathrm{m} / z 39$ $[\mathrm{K}]^{+}, m / z 46\left[\mathrm{Na}_{2}\right]^{+}$, and $m / z 81$ and $m / z 83\left[\mathrm{Na}_{2} \mathrm{Cl}\right]^{+}$, whilst in the ATOFMS negative spectra $\mathrm{m} / \mathrm{z}-23[\mathrm{Na}]^{-}, \mathrm{m} / \mathrm{z}-35$ and $-37[\mathrm{Cl}]^{-}$were dominant. Along with the peaks described for the pure sea salt particles, additional peaks at $\mathrm{m} / \mathrm{z}$ $63\left[\mathrm{HNO}_{3}\right]^{+} /\left[\mathrm{Na}_{2} \mathrm{OH}\right]^{+},\left[\mathrm{NO}_{2}\right]^{-}(\mathrm{m} / z-46)$ and $\left[\mathrm{NO}_{3}\right]^{-}$ $(\mathrm{m} / \mathrm{z}-62)$ were present for the aged sea salt particle type. There particle types were previously classified indicating the reaction between $\mathrm{NaCl}$ and $\mathrm{HNO}_{3}$ and the replacement of chloride by nitrate (Gard et al., 1998; Dall'Osto et al., 2004). No pure sodium nitrate particles were found during this field study, but all the aged sea salt particles were internally mixed with both chloride and nitrate.

The ATOFMS revealed a main particle type for the $m T$ period. This particle type was in the coarse mode $(1-2 \mu \mathrm{m}$ in size) and it was found to be internally mixed with organic carbon, sea salt, sulphate and MSA. Interestingly, peaks at $\mathrm{m} / \mathrm{z}$ 48 and $\mathrm{m} / z 64$ ( $\mathrm{Ti}$ and $\mathrm{TiO}$, respectively) were also present in the ATOFMS positive mass spectrum, suggesting that dust was internally mixed with sea salt, carbon and MSA. Titanium rich particles (along with aluminosilicate) were already identified during the NAMBLEX project under air masses (Dall'Osto et al., 2004) originated from the Azores highpressure region which drawn air from North Africa. The ATOFMS used for the EUCAARI field study was equipped with aerodynamic lens, which focuses single particles in a different way that the previous ATOFMS version used during the NAMBLEX project (where air is introduced into the ATOFMS via a vacuum system region through a converging nozzle followed by two differentially pumped regions separated by skimmers which finally create a narrow collimated particle beam). No dust Ti-rich particle types were found during the EUCAARI intensive field study, and the reason is likely to be due to the inefficiency of the aerodynamic lens to focusing dust particles. However, two other dust particle types were monitored during the EUCAARI field study. The former dust particle type was found to be rich in iron (this ATOFMS particle type represented $0.9 \%$ of the total particles sampled and its positive mass spectrum showed signals dominated by $\mathrm{m} / \mathrm{z} 54$ and $\mathrm{m} / \mathrm{z}$ 56). Interestingly, this particle type presented similar temporal trends of the Nitrate-rich particle type, indicating transport of iron containing aerosol from continental Europe and likely to be important in the iron deposition in the North Atlantic (Baker and Croot, 2009). The latter represented $0.4 \%$ of the particles sampled and was named V-rich after its peculiar ATOFMS positive particle mass spectrum dominated by $\mathrm{m} / \mathrm{z} 51$ [V] and $\mathrm{m} / \mathrm{z}, 67$ [VO]. Vanadium and nickel are usually used as tracers for oil combustion sources. This particle type was found only during the first two weeks of the field study, when air masses where coming from Continental Europe. No V-rich particle types were found coming from the other 3 marine air masses $(m P$, $m A$ and $m T$ ) excluding a contribution from ship emissions. The fact that more V-rich particle types were found more within the former 2 weeks of the field study respect the latter 2 weeks suggest that the Vanadium contribution from oil combustion might be higher than the ones due to ship emissions.

\subsubsection{Off-line chemistry}

During the intense campaign seven aerosol samples for offline chemical analyses were collected: five samples during the $c P$ period, one during the $m P$ period and one during the $m A$ period. No samples were collected for the $c m P$ period and the $m P$ period. Concentrations referring to the $c P$ period 

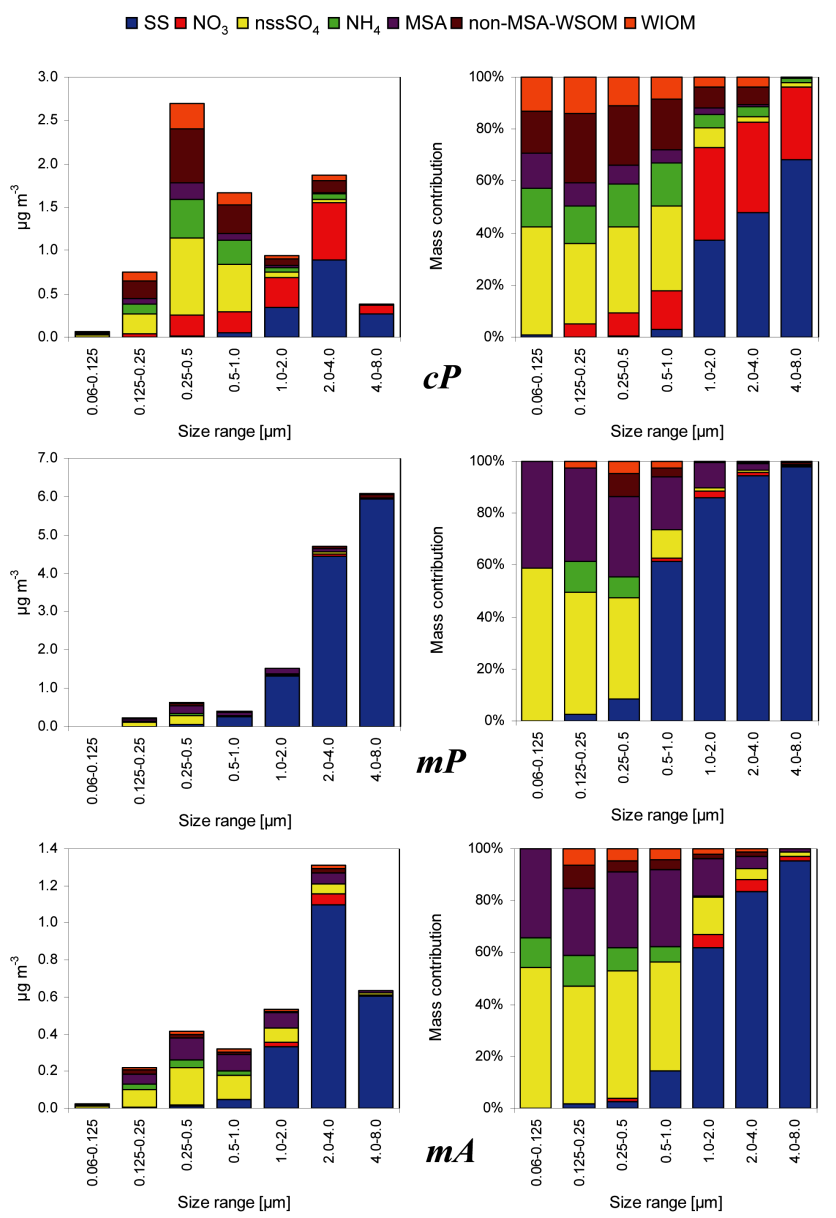

Fig. 11. Absolute (left panel) and relative (right panel) chemical composition of the aerosol samples collected in $c P, m P$ and $m A$ air masses.

are reported as the average of the five samples \pm the standard deviation, while the single sample values are indicated for periods $m P$ and $m A$. Figure 11 shows the absolute (A) and relative (B) chemical composition of particles collected during period $c P, m P$ and $m A$ as a function of size. Continentally influenced air masses were characterized by higher submicron particle loads than clean marine ones: total submicron analyzed mass was $5.2 \pm 2.0,1.3$ and $0.98 \mu \mathrm{g} \mathrm{m}^{-3}$ in $c P, m P$ and $m A$ air masses, respectively.

The highest supermicron particle load was observed in the $m P$ sample: $12 \mu \mathrm{g} \mathrm{m}^{-3}$, against $3.2 \pm 1.1$ and and $2.5 \mu \mathrm{g} \mathrm{m}^{-3}$ measured in $c P$ and $m A$ air masses, respectively. Being coarse mass, in clean marine aerosol, determined mainly by sea salt, the high coarse particle load of the $m P$ sample must reflect higher wind speed and rougher sea conditions during period $m P$.

Continentally influenced aerosol presented a bimodal mass size distribution with the mass peak in the $0.25-0.5 \mu \mathrm{m}$ size range and a second mode centred in the $2.0-4.0 \mu \mathrm{m}$ size ranges; marine aerosol mass size distribution was, on the contrary, dominated by large particles, with mass peaks in the $4.0-8.0$ or $2.0-4.0 \mu \mathrm{m}$ size ranges. Similar chemical compositions were observed between the two clean marine samples, while larger differences were observed between continentally influenced and clean marine samples, both in fine and coarse fraction. An average submicron nss-sulphate concentration of $1.7 \pm 0.4 \mu \mathrm{g} \mathrm{m}^{-3}$ was observed during period $c P$, accounting for $33 \%$ of the analyzed submicron mass, while sulphate concentrations were $0.40(32 \%)$ and $0.45 \mu \mathrm{g} \mathrm{m}^{-3}(45 \%)$ during periods 3 and 5 , respectively. A substantial contribution of nitrate in submicron particles characterized period 1 $\left(0.53 \pm 0.60 \mu \mathrm{g} \mathrm{m}^{-3}\right.$, accounting for $10 \%$ of the mass), while nitrate contribution during periods 3 and 5 was only 0.4 and $1 \%$, respectively, due to concentrations of the order of few nanograms per cubic meter. Submicron ammonium concentration was $0.84 \pm 0.36 \mu \mathrm{g} \mathrm{m}^{-3}(16 \%)$ during period 1 , $0.076 \mu \mathrm{g} \mathrm{m}^{-3}(6 \%)$ during period 3 and $0.085 \mu \mathrm{g} \mathrm{m}^{-3}$ (9\%) during period 5. Sea salt contributed to submicron mass with $0.061 \pm 0.023(1 \%), 0.31(24 \%)$ and $0.060 \mu \mathrm{g} \mathrm{m}^{-3}(6 \%)$ in $c P, m P$ and $m A$ air masses, respectively.

MSA was the main organic compound identified in both continentally influenced and clean marine air masses. MSA concentration was $0.36 \pm 0.08,0.36$ and $0.28 \mu \mathrm{g} \mathrm{m}^{-3}$ in $c P$, $\mathrm{mP}$ and $\mathrm{mP}$ air masses, respectively, accounting for $7 \%$ of submicron mass in continentally influenced air masses and $29 \%$ in both clean marine samples. Moreover, MSA accounted for about $50 \%$ of the water soluble organic carbon in clean marine samples and only $7 \%$ in continentally influenced air masses. Previously reported MSA contributions to WSOC concentrations measured in clean marine air masses at Mace Head are $\sim 15 \%$ (Facchini et al., 2008a) - the current results reflect the natural variability of the N. E. Atlantic biosphere.

For example, MSA concentrations measured during the campaign were almost an order of magnitude higher than the concentrations published by Yoon et al. (2007) for the same site, in the same period of the year, and about threefold higher than the maximum value reported for the month of July. In fact, preliminary evaluation of MSA levels using the HR-ToF-AMS elude to concentrations 2-3 times higher in $m T$ air compared to the other air masses outlined above. Comparably high concentrations have been reported by other investigators (McArdle et al., 1996; Savoie et al., 2002) at Mace Head. The $\mathrm{nsSSO}_{4}^{-2} / \mathrm{MSA}$ molar ratio was $4.7 \pm 1.6,1.1$ and 1.6 in periods $c P, m P$ and $m P$, respectively. Savoie et al. (2002) proposed $3.01( \pm 0.53)$ as marine biogenic $\mathrm{nssSO}_{4}^{-2} / \mathrm{MSA}$ ratio at Mace Head: the lower ratio characterising the clean marine samples during the campaign can be attributed to the high latitude origin of the air masses (Bates et al., 1992; Kerminem and Leck, 2001). The pretty low $\mathrm{nsSO}_{4}^{-2} / \mathrm{MSA}$ molar ratio of period 1 suggests a substantial biogenic marine contribution also during period $c P$. The $\mathrm{nssSO}_{4}^{-2} / \mathrm{MSA}$ molar ratio derived from the AMS measurements are of the order of 2-5 times higher than for the impactor data (Table 4), presumably due to the notable 
Table 4. Ratios of nss-Sulphate to MSA for the AMS and impactor measurements.

\begin{tabular}{ccc}
\hline \multirow{2}{*}{ Period } & \multicolumn{2}{c}{ Ratio nssSO } \\
\cline { 2 - 3 } & AMS & Impactors \\
\hline$c P$ & 13.3 & 4.7 \\
$c m P$ & 21.4 & NA \\
$m P$ & 5.1 & 1.1 \\
$m T$ & 6.4 & NA \\
$m A$ & 5.8 & 1.6 \\
\hline
\end{tabular}

supermicron fraction of MSA in the impactor samples (see below) which is not characterized by the AMS.

Finally, different MSA size distributions were observed for anthropogenic influenced and clean marine aerosol samples: during period $c P$, MSA was prevalently present in the submicron fraction, with a fine-to-coarse ratio of 8.9, while the ratio lowered to 1.3 and 1.9 in samples collected in $m P$ and $m A$ air masses, respectively. This different can be due to the different chemical composition of the coarse fraction in clean and polluted aerosols (see below) influencing the partitioning of MSA.

Submicron non-MSA-WSOM concentration was $1.2 \pm 0.5(22 \%), 0.068(5 \%)$ and $0.048(5 \%) \mu \mathrm{g} \mathrm{m}^{-3}$ in $c P, m P$ and $m A$ aerosol samples, respectively, while WIOM concentration was $0.55 \pm 0.41(11 \%), 0.045(4 \%)$ and 0.047 $(5 \%) \mu \mathrm{g} \mathrm{m}^{-3}$. The composition of WIOM has not been investigated, however in anthropogenic influenced particles it represents mainly primary emissions by fossil fuel, and eventually biomass, burning comprising also $\mathrm{BC}$, not speciated by the employed analytical technique. In clean marine samples the contribution of BC to WIOM can be considered negligible and WIOM can be associated almost entirely to primary production from the ocean surface (Facchini et al., 2008b). The contribution of primary and non-MSA secondary organics in clean marine aerosols during the campaign resulted lower than reported in previous papers (O'Dowd et al., 2004; Cavalli et al., 2004).

Submicron particles acidity showed sensitive differences between continentally influenced and clean marine aerosols. Following the approach of Ziemba et al. (2007), submicron aerosol acidity was estimated by the equivalent ratio between $\mathrm{NH}_{4}^{+}$and the sum of $\mathrm{NO}_{3}^{-}, \mathrm{SO}_{4}^{-2}$ and $\mathrm{MS}^{-}$. Submicron anthropogenic influenced aerosol resulted almost neutralized (ratio $=0.98 \pm 0.04$ ), while clean marine particles presented ratios of $0.35(\mathrm{mP})$ and $0.38(\mathrm{~mA})$ typical of acid particles. Supermicron particles chemical composition was dominated by sea salt in clean marine aerosol samples $\left(12 \mu \mathrm{g} \mathrm{m}^{-3}(96 \%\right.$ of the mass) and $2.0 \mu \mathrm{g} \mathrm{m}^{-3}(82 \%)$ in $m P$ and $m A$ air masses, respectively). Sea salt was an important component also in anthropogenic influenced aerosol $\left(1.5 \pm 0.9 \mu \mathrm{g} \mathrm{m}^{-3}, 47 \%\right.$ of

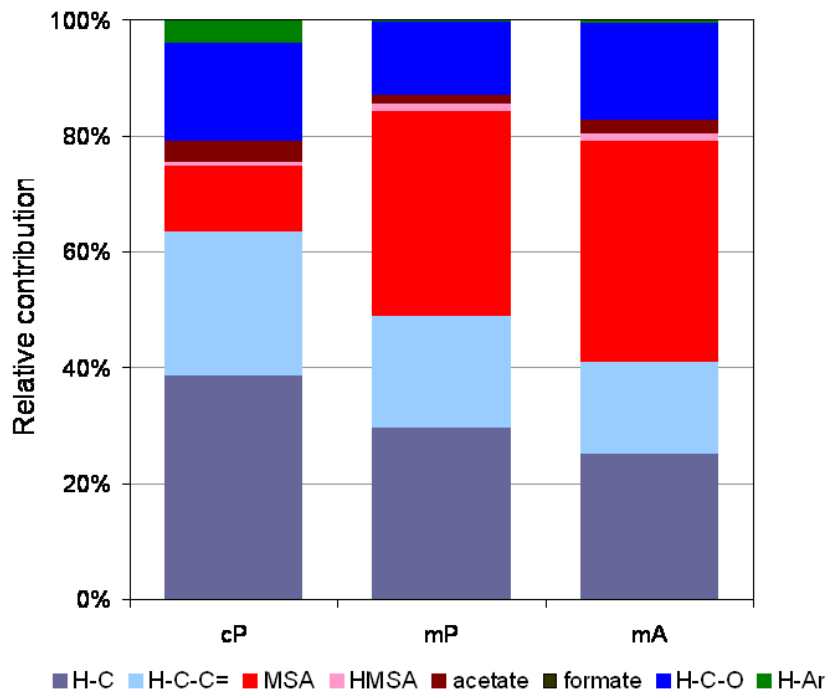

Fig. 12. $1 \mathrm{H}$ NMR chemical characterization of WSOC as a function of the air mass origin

the mass). $\mathrm{NO}_{3}^{-}$was the second major component of coarse particles during period $c P\left(1.1 \pm 0.5 \mu \mathrm{g} \mathrm{m}^{-3}, 34 \%\right)$, suggesting a significant contribution of secondary processes involving coarse sea salt particle, mainly the reaction between nitric acid and sodium chloride, producing sodium nitrate and hydrochloric acid. Processing was evident also in clean marine samples with nitrate contributing $0.10 \mu \mathrm{g} \mathrm{m}^{-3}(1 \%)$ and $0.12 \mu \mathrm{g} \mathrm{m}^{-3}(4 \%)$ during period $m P$ and $m A$. A contribution from crustal components cannot be excluded during period $c P$ even though they cannot be quantified by the employed characterization techniques.

1H-NMR spectral features of clean marine submicron aerosols were remarkably different with respect to those characterizing the anthropogenic-influenced samples (Fig. 12). In particular MSA signal accounted for up to one third of the total detected signal in clean marine samples while contributed in much less extent to the $c P$ samples. Beside MSA, the most abundant aliphatic moieties are those containing unsubstituted saturated carbon atoms (H-C) in all three samples types, and the ratio of $\mathrm{H}-\mathrm{C}$ groups to substituted aliphatic groups, $\mathrm{H}-\mathrm{C}-\mathrm{O}$ and $\mathrm{H}-\mathrm{C}-\mathrm{C}=$, is not remarkably different for $m A$ and $m P$ with respect to $c P$, suggesting a similar degree of functionalization of aerosol WSOC characterizing the three air masses. However, the speciation of aliphatic functionalities changes between samples, with the $m A$ case showing the highest proportion of alcohols/ethers (H-C-O), while $m P$ and $c P$ exhibit a relatively higher contribution from aliphatic groups adjacent to carbonyls, carboxyls and other unsaturated structures (H-C-C $=)$. Therefore, the samples of clean marine air show variations in their WSOC composition related to air mass origin.

Anthropogenic-influenced samples present a higher fraction of aromatic hydrogen atoms (3.8\%) with respect to clean 
marine ones ( 0.38 and $0.55 \%$ in $m P$ and $m A$ respectively). The low aromatic content of $c P$ samples compared to "typical" pollution aerosols in continental areas (7-10\% according to Matta et al., 2003; Mayol-Bracero et al., 2002 and Decesari et al., 2007) can result from the mixing with marine particulate organic compounds (which are mainly aliphatic) and possibly from oxidative degradation of the aromatic moieties during the transport from the source areas in Europe. HMSA (hydroxymethanesulfonate), which is formed in the atmosphere by the reaction of $\mathrm{SO}_{2}$ with formaldehyde, was clearly detected in all the samples. Others identified single compounds such as acetate and formate were found in both clean marine and anthropogenic influenced samples.

\subsection{Aerosol hygroscopicity}

As in the SMPS data analysis, periods with nucleation were removed from the H-TDMA analysis. The H-TDMA showed significantly different GFs for aerosols occurring under different air masses (Fig. 13). The GF-PDF for $c P$ and $c m P$ air masses exhibited peaks all below 1.45 at different sizes $(35 \mathrm{~nm}, 50 \mathrm{~nm}, 75 \mathrm{~nm}, 110 \mathrm{~nm}, 165 \mathrm{~nm})$, whilst all the GF for the other 3 air masses ( $m P, m T$, and $m A$ ) show GF peaks above 1.35 and below 1.5. This range of GFs indicates that the majority of particles have GFs notably less than ammonium sulphate for the selected sizes (Nilsson et al., 2009). With the current instrument configuration, it could not be discerned what fraction of the aerosol had GFs corresponding to pure sea-salt $(\mathrm{GF}=2.2)$.

More specifically, $c P$ air masses exhibit a large difference in GFs (broad peaks between 1.2 and 1.5) across sizes suggesting a different chemical composition for particles of different sizes, slowing the GF shifting towards higher values as the particle diameter increases (progression from $35 \mathrm{~nm}$ sizes with GF $\sim 1.27 \pm 0.05$ to $165 \mathrm{~nm}$ sizes with GF $\sim 1.38 \pm 0.05$ ). A second mode at about $1-1.2$ can be seen in the GF-PDF for the $c P$ case, indicating a small fraction of very low solubility particles. $\mathrm{cmP}$ air masses exhibit a different GF-PDF distribution compared to the $c P$ air masses, with generally lower GFs for all sizes. At least 3 particle types with 3 different GF from 1.0 to 1.5 can be seen under these conditions, with a reducing GF for reducing particle sizes. The contrasting and lower GFs associated with $\mathrm{cm} P$ air masses compared to $c P$ air masses suggest a greater amount of less oxidized organic aerosol associated with the $\mathrm{cmP}$ air masses and point to more local sources of organic aerosol. $m P$ air masses probably represented the simplest group, with a GF of $1.45 \pm 0.05$ for all the different sizes showing an internally mixing state and one broad type of particles at least for sizes at 35 and $50 \mathrm{~nm}$. The bigger sizes $(110 \mathrm{~nm}$ and $165 \mathrm{~nm})$ show a broader GF-PDF distribution across smaller GF suggesting a contribution of a less soluble particle type at higher sizes. The $m T$ period shows similar GF-PDF for mid-sized particles at $50 \mathrm{~nm}$ and $75 \mathrm{~nm}$, with average GF at $1.5 \pm 0.09$, and for the smallest and largest

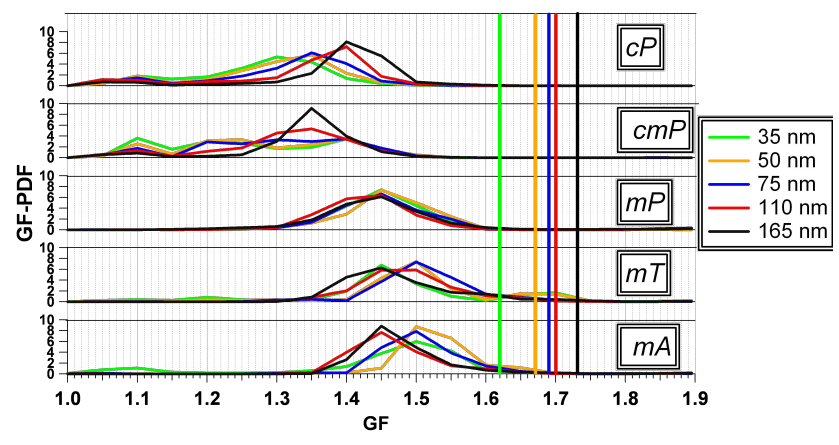

Fig. 13. Hygroscopic growth factors for $35,50,75,110$, and $165 \mathrm{~nm}$ dry particles for $c P, c m P, m P, m T$ and $m A$ air masses. Also shown, in the vertical lines are the growth factors for pure ammonium sulphate for the corresponding colour coded dry sized particle. Growth Factors in the measurements are limited to a maximum of 2 and therefore do not capture Growth Factors of 2.2 associated with pure sea-salt.

sizes sampled ( $35 \mathrm{~nm}$ and $165 \mathrm{~nm})$ a slightly lower GF of $1.47 \pm 0.1$ is observed. The $m A$ period, similar to the $m T$ period, comprises two GF modes for two groups of particle sizes: namely GF $\sim 1.45$ for $110 \mathrm{~nm}$ and $165 \mathrm{~nm}$ particles, and $\mathrm{GF} \sim 1.52$ for 35,50 and $75 \mathrm{~nm}$ particle sizes. A detectable mode at 1.1 can also be seen $35 \mathrm{~nm}$ particles, indicating a contribution of small particles with very low water solubility.

The above GF results are indicative of significant deviations from a marine aerosol population dominated by nsssulphate, although it is not possible to comment on the similarity to sea-salt. GFs are always notably less that of pure ammonium sulphate GFs. Depending on the size being considered, significant enhancement of secondary organic aerosol amongst the smallest sizes, and significant enhancement of primary marine organic aerosol is consistent with the observations. These GF results are in stark contrast to GF studies reported in other oceanic regions, as summarized below; however, they are consistent with the emerging picture of N. E. Atlantic marine aerosol being significantly enriched in both water soluble and water insoluble organic aerosol (O'Dowd et al., 2004). In particular, comprehensive field studies in the past include the Aerosol Characterization Experiments ACE 1, ACE 2 and ACE 3 which determined the physical, chemical, and optical properties of aerosols in the marine boundary layer over the Pacific and Southern Oceans and over the eastern Northern Atlantic Ocean (Berg et al., 1998; Swietlicki et al., 2000) and the Southern Atlantic Ocean or the Indian Ocean (Massling et al., 2003).

The average GFs for the studies of Massling et al. (2003) at $90 \% \mathrm{RH}$ ranged between 1.66 and 1.74 for $50 \mathrm{~nm}$ particles, between 1.80 and 1.93 for $150 \mathrm{~nm}$ particles, and between 1.84 and 2.03 for $250 \mathrm{~nm}$ particles. These values agreed with those for marine aerosols measured during experiments conduced over the Pacific Ocean and Southern Ocean, namely, 
1.66 for $50 \mathrm{~nm}$ particles and 1.78 for $150 \mathrm{~nm}$ particles (Berg et al., 1998). However, the average GFs for the clean marine air masses ranged between 1.66 and $1.74(50 \mathrm{~nm}), 1.86$ and $1.93(150 \mathrm{~nm})$, and 1.91 and $2.03(250 \mathrm{~nm})$. In general, relatively high GFs of more hygroscopic particle fractions correspond well with the measured chemical inorganic composition. For most time periods, ammonium ions and sulfate ions dominated the molar distribution, signifying that the major inorganic compounds were hygroscopically active material, such as ammonium sulfate, ammonium bisulfate, and sulfuric acid. In addition, during clean marine air mass conditions at Puerto Rico (Allan et al., 2008), the submicron aerosol was observed to be almost entirely inorganic and supported by hygroscopicity observations where the GF spectra showed a consistent mode around 1.5-1.6. This is quite close to the GF that are predicted for ammonium sulphate. More recently (Allan et al., 2009) again reported GFs of about 1.61.8 for different particle sizes during clean marine conditions encountered in the Eastern Atlantic area of Cape Verde.

Our study shows clearly lower GF, implying probably a different chemical composition, likely to be due to less soluble organic components. Our studies support the finding of Sellegri et al. (2009).

\subsection{CCN properties}

Figure 14 shows that the $\mathrm{CCN}$ total number concentrations had the same trends going from polluted to progressively cleaner air masses, showing a decrease in number concentration. Peak CCN concentrations of $\sim 1600 \mathrm{~cm}^{-3}$ occurred in $c P$ air masses for supersaturations of $0.5 \%-1 \%$, decreasing to $740 \mathrm{~cm}^{-3}$ at a supersturation of $0.1 \%$. in $\mathrm{cm} P$ air, peak concentrations of $\sim 1300 \mathrm{~cm}^{-3}$ were observed for $0.5 \%-1 \%$ supersaturation, decreasing to $\sim 530 \mathrm{~cm}^{-3}$ at $0.1 \%$ supersaturation. For both $c P$ and $m c P$ air masses, the concentration of $\mathrm{CCN}$ between $0.5 \%$ and $1 \%$ supersaturation does not effectively change, indicating all $\mathrm{CCN}$ are activated at $0.5 \%$ supersaturation. The $m T$ and $m A$ supersaturation spectra are more or less identical, with $\sim 400 \mathrm{~cm}^{-3}$ nuclei activated at $1 \%$ supersaturation, decreasing to $\sim 200 \mathrm{~cm}^{-3}$ for $0.1 \%$ supersaturation (specifically $230 \mathrm{~cm}^{-3}$ and $166 \mathrm{~cm}^{-3}$ for $m A$ and $m T$, respectively. In terms of $\mathrm{CCN}$ activation ratio (i.e. the ratio of $\mathrm{CCN}$ activated at a give supersaturation over the total condensation nuclei concentration at sizes $d>10 \mathrm{~nm}$ ), the lowest ratio occurred for the $\mathrm{cmP}$ air mass, increasing from 0.15 at $0.1 \%$ supersaturation to $\sim 0.4$ at $1 \%$ supersaturation. In $c P$ air, the ratio ranges from 0.2 to 0.5 over the same range of supersaturations. For both $m A$ and $m T$ air masses, the ratio ranges from $0.4-0.7$ over the same range of supersaturations. During this campaign, CCN data was not available for the $m P$ air mass period.

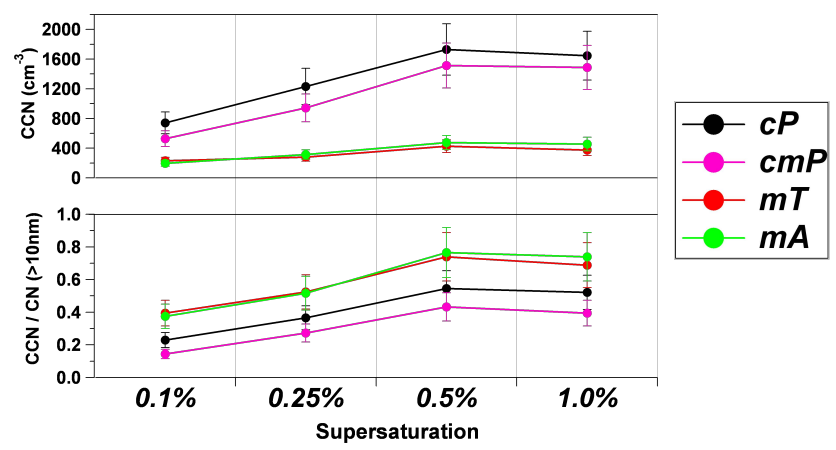

Fig. 14. (Top) CCN concentrations as a function of supersaturation and air mass classification. (Bottom) Ratio of CCN to total Condensation Nuclei at sizes larger than $10 \mathrm{~nm}$ diameter.

\subsection{Aerosol optical properties}

A Black Carbon (BC) mass attenuation efficiency of $16.6 \mathrm{~m}^{2} \mathrm{~g}^{-1}$, specified by the Aethalometer manufacturer, Magee Scientific, was used in this work to convert the aerosol absorption data into BC mass concentrations. Aerosol absorption data for this intensive field study were in line with previous results (Junker et al., 2006), with aerosol light absorption of $5.2 \pm 2.66 \mathrm{Mm}^{-1}$, $4.61 \pm 1.69 \mathrm{Mm}^{-1}, \quad 0.56 \pm 0.33 \mathrm{Mm}^{-1}, 0.74 \pm 0.41 \mathrm{Mm}^{-1}$ and $0.38 \pm 0.26 \mathrm{Mm}^{-1}$ for $c P, c m P, m P, m T$ and $m A \mathrm{M}$, respectively.

Nephelometer scattering data for this field study are shown in Fig. 15 for different wavelength and different periods of the field study. A progressive decrease over the five periods can be seen for all the 3 wavelengths. However, different behaviors can be further noticed when the ratio between the signals obtained from different wavelength is calculated. The $m P$ period shows the highest ratio for $700 \mathrm{~nm} / 450 \mathrm{~nm}$ wavelengths and 550/450 wavelengths ratios, implying coarser particles (sea salt - as seen from the impactor chemical analysis). A contrasting trend is seen for the $c P$ period, suggesting a higher number of smaller particles during this period.

AOD values were highest in the $c P$ air mass with values slightly in excess of 0.35 at $367.6 \mathrm{~nm}$ wavelength, decreasing to $\sim 0.15$ at $863.1 \mathrm{~nm}$ wavelength. The next largest AOD values were encountered in the $\mathrm{cm} P$ air mass, ranging from $\sim 0.25$ at $367.6 \mathrm{~nm}$ to $\sim 0.1$ at $863.1 \mathrm{~nm}$. $c P$ air exhibited AOD values ranging from $\sim 0.2$ at $367.6 \mathrm{~nm}$ to $\sim 0.15$ at $863.1 \mathrm{~nm}$. Finally, $m A$ air exhibited AOD values ranging from $\sim 0.15$ at $367.6 \mathrm{~nm}$ to $\sim 0.05$ at $863.1 \mathrm{~nm}$. The values of $\mathrm{AOD}$ at $501 \mathrm{~nm}$ in $c P, \mathrm{~cm} P, m P$ and $m A$ are $\sim 0.25, \sim 0.17$, $\sim 0.15$ and $\sim 0.1$, respectively. No AOD was recorded during $m T$ air due to complete cloud cover through that period. The spectral shape of the continentally-influenced air masses demonstrate a sharper fall-off in AOD at longer wavelengths compared to the maritime air masses, suggesting a lesser influence of supermicron particles on AOD. What is also interesting is the fact that the $\mathrm{cmP}$ AOD is notably less 
that that associated with $c P$ air, despite the remarkable similarities in microphysical properties such as size distribution and number concentration. However, differences are more clear in GFs between the two air mass categories in that $\mathrm{cmP}$ aerosol possesses a significantly lower growth factor that aerosol in $c P$ air masses. Average relative humidity in $c P$ air was $\sim 80 \%$ while in $\mathrm{cm} P$ relative humidity was $\sim 90 \%$. Despite the higher relative humidity in $c m P$ air, $c P$ aerosol contributes to a greater AOD. Consequently, the difference in AOD between the two air masses seems to be largely due to the aerosol GF, and consequently, chemical composition.

These results (Figs. 15 and 16) are similar to those reported by Mulcahy et al. (2009) who reported $501 \mathrm{~nm}$ AOD values of 0.14 under marine conditions and 0.19 for continentals conditions. It should be noted that in Mulcahy et al. (2009), peak AOD in clean air reached 0.4 and was attributed to increased sea spray under high wind conditions (Mulcahy et al., 2008) and peak AOD values in continental air was of the order of 0.5 for the most polluted case. The AOD in the marine cases at $500 \mathrm{~nm}$ is in reasonable agreement, although generally larger than baseline AOD values of 0.07 over the Atlantic Ocean (Kaufman et al., 2001) and of 0.11 over the North Atlantic Ocean as measured by Villevalde et al. (1994).

\section{Discussion}

A comprehensive set of meteorological and aerosol physicochemical measurements were undertaken as part of the EUCAARI Mace Head Intensive Observing Period. The results characterize, in the most comprehensive manner to date, aerosol properties as a function of air masses entering (import of hemispheric pollution) and exiting (export of pollution to the N. E. Atlantic) Europe. From a meteorological perspective, wind speeds, temperatures and relative humidities were typical of the temperate latitudes associated with the measurement location. Period-average wind speeds ranged from 6-13 $\mathrm{m} \mathrm{s}^{-1}$ while temperatures ranged from 13$14.5^{\circ} \mathrm{C}$ and relative humidity ranged from $80-92 \%$. Five typical air masses, common to the region, were encountered. Two of these were polluted continental and three were clean marine. During all conditions, the marine boundary layer comprised two decoupled layers - a surface mixed layer and a decoupled residual/convective layer. The surface layer ranged from $500 \mathrm{~m}$ to $2000 \mathrm{~m}$ while the top of the boundary layer (also the top of the residual layer) ranged from $1500 \mathrm{~m}$ to $2500 \mathrm{~m}$.

The two polluted cases were associated with high pressure systems over Europe and differed in that the $c P$ case transported significant pollution, under moderately strong easterly winds, from central Europe to Mace Head and was likely to comprise predominately aged pollution. In contrast, the $\mathrm{cmP}$ case, with the centre of the associated high located over or close to Mace Head, was characterized by low winds and

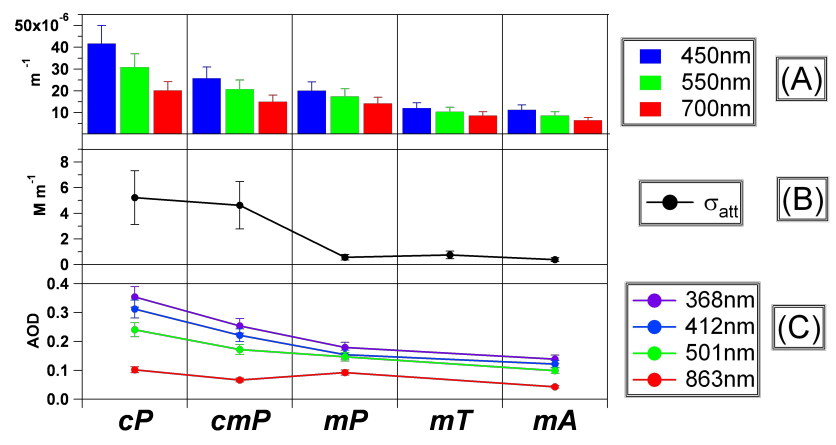

Fig. 15. (A) $450 \mathrm{~nm}, 550 \mathrm{~nm}$, and $700 \mathrm{~nm}$ scattering coefficient as a function of air mass categories, (B) absorption coefficient as a function of air mass categories. (C) Aerosol Optical Dept as a function of $368 \mathrm{~nm}, 412 \mathrm{~nm}, 501$ and $863 \mathrm{~nm}$ wavelengths and aor mass categoties.

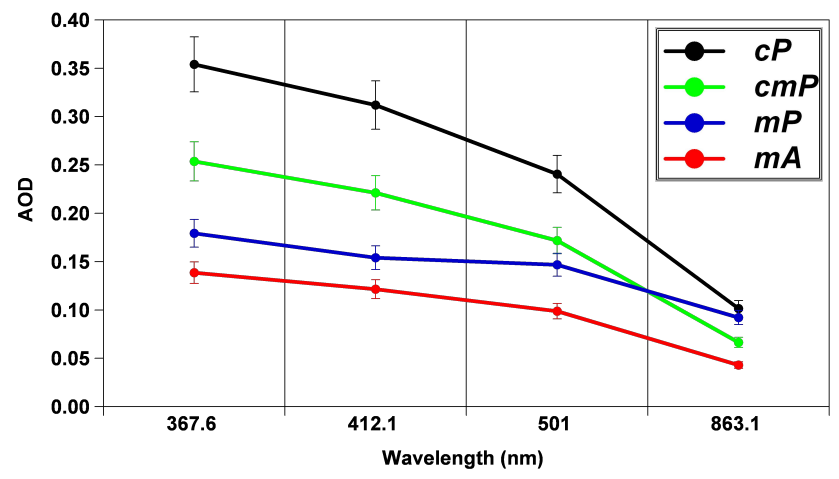

Fig. 16. Aerosol Optical Dept spectral dependence by air mass category.

stagnant air flow and was likely to comprise a significant fraction of local, and consequently, less aged pollution.

Both polluted air masses exhibited remarkable similarities in their aerosol concentrations and size distribution shapes. Concentrations were $3261 \mathrm{~cm}^{-3}$ for $c P$ air and $3044 \mathrm{~cm}^{-3}$ for $m c P$, both with a dominant modal diameter at $60 \mathrm{~nm}$. The chemical composition (excluding refractory sea salt) was dominated by organic matter, followed next by sulphate mass and then notable amounts of nitrate. The highest organic mass occurred for the $\mathrm{cmP}$ case. Black carbon mass, using the MAAP instrument, was similar for both cases with mass loadings $\sim 328-388 \mathrm{ng} \mathrm{m}^{-3}$. Aerosol GFs were significantly lower in the $\mathrm{cmP}$ case and GF modes as low as 1.1 were more prominent in $\mathrm{cmP}$ air. The lower aerosol solubility, inferred from the GFs, was also reflected in the $\mathrm{CCN} / \mathrm{CN}$ ratio being lower for the $c m P$ case compared to the $c P$ case ( 0.14 at $0.1 \%$ supersaturation for the $\mathrm{cm} P$ case increasing to 0.4 at $1 \%$, compared to 0.23 at $0.1 \%$ and 0.55 at $1 \%$ supersaturation for the $c P$ case). The more soluble characteristics of $c P$ air points to a more aged pollution aerosol as the organic fraction is likely to be more oxidized.

In terms of optical properties, the absorption coefficient was quite similar in both cases $\left(\sigma=5.2 \mathrm{Mm}^{-1}\right.$ for $c P$ air 
and $\sigma=4.6 \mathrm{Mm}^{-1}$ for $\mathrm{cmP}$ air); however, greater differences were seen between the two air masses for aerosol $550 \mathrm{~nm}$-scattering $\left(3.09 \mathrm{Mm}^{-1}\right.$ and $2.08 \mathrm{Mm}^{-1}$, respectively, or $50 \%)$ and $501 \mathrm{~nm}$-AOD (0.24 and 0.17 , respectively, or $40 \%$ ). The significantly higher scattering and AOD levels associated with the $\mathrm{cP}$ air mass, which is in fact characterized by a lower relative humidity ( $80 \%$ compared to $90 \%$ ), given the similarities in number concentration and spectral shape, suggests that the difference in aerosol GFs, resulting from the degree of aging, accounts for a significant component of the aerosol radiative properties.

For marine cases, tropical, polar and Arctic air masses were encountered. All cases represented clean conditions and low particle concentrations of between $\sim 400 \mathrm{~cm}^{-3}$ and $\sim 1100 \mathrm{~cm}^{-3}$, the highest concentrations occurring for the $m P$ case. The aerosol size distributions were clearly bi-modal with an Aitken mode between 40 and $60 \mathrm{~nm}$ and an accumulation mode between 200 and $300 \mathrm{~nm}$, the larger mode diameter occurring for $m T$ air. The concentrations of the Aitken and accumulation modes were very similar for all three air masses; however, a third mode at $15 \mathrm{~nm}$ was observed in the $m P$ case. This third mode accounts for the $\sim 30 \%$ higher concentration associated with $m P$ air compared to $m T$ and $m A$ air. This mode is a recently formed nucleation mode, thought to be formed over the open ocean. If we assume a nucleation mode growth rate of $1 \mathrm{~nm} \mathrm{~h}^{-1}$, and taking the average wind speed for $m P$ air of $12.5 \mathrm{~m} \mathrm{~s}^{-1}$, this would imply a source region $\sim 675 \mathrm{~km}$ off shore.

The chemical composition of the marine aerosol cases in supermicron sizes is, as expected, predominantly comprised of sea-salt. For submicron sizes, sulphate contributed the largest single component (up to $50 \%$ in the smallest sizes). The AMS indicates that the highest sulphate mass occurs for the $m T$ case, although this cannot be corroborated by the off-line measurements as the were not available for $m T$ air; however, it is consistent with previous studies (Yoon et al., 2007). As discussed, above, the AMS sulphate mass in marine air is likely to be somewhat contaminated by MSA. From the off-line impactor chemical data, MSA is the single most important organic species in marine air, with concentrations up to $40 \%$ in the smallest sizes in $m P$ air. MSA is significantly higher during this campaign compared to previous campaigns at the same location and using the same techniques (Yoon et al., 2007). In addition, the water insoluble organic mass component is also significantly less that previous reports at the same location (O'Dowd et al., 2004). Black carbon was between 17 and $44 \mathrm{ng} \mathrm{m}^{-3}$, consistent with clean air mass definitions over the N. E. Atlantic.

Differences between $m P$ and $m A$ periods were evident in the chemical composition of the submicron aerosol where in the former air mass, carboxylic and carbonylic structures were the main contributors of the oxidized fraction and in the latter air mass, alcohol structures accounted for $51 \%$ of the oxidized functional groups.

\section{Conclusions}

Anthropogenic air advecting out of Europe and into the N. E. Atlantic comprises aerosol concentrations of the order of $3000 \mathrm{~cm}^{-3}$ and a size distribution mode of the order of $60 \mathrm{~nm}$. By comparison, marine air entering into Europe via latitudes of $54^{\circ} \mathrm{N}$, whether tropical, polar or Arctic, exhibit concentrations of the order of $400-600 \mathrm{~cm}^{-3}$, but with concentrations as high as $1100 \mathrm{~cm}^{-3}$ occurring in polar air. All marine air size distributions display clear bimodality with an Aitken and accumulation mode. Polar air also exhibited a recently-formed nucleation mode at $\sim 15 \mathrm{~nm}$, indicative of an open ocean source of new particles. The highest organic matter loadings occurred in the two continental cases and dominate submicron mass loadings in both cases. Sulphate contributed less than organics in polluted air, but more so than nitrate. MSA contributed the dominant water soluble organic fraction in marine air masses and contributed up to $30 \%$ of the aerosol mass at certain sizes. Water insoluble organic mass contributed significantly less to submicron aerosol mass than previously report, while the MSA fraction was at least double than previously reported (Yoon et al., 2007). All air masses exhibited hygroscopic GFs significantly less than ammonium sulphate and even more so than sea salt. The GF-PDF peaks at 1.35-1.4 for the two continental cases and 1.45-1.5 for the marine cases. In both categories, GFs do not reflect GFs for ammonium sulphate suggesting significant organic enrichment or coating around inorganic cores.

Acknowledgements. This work was funded by the European Commission Framework Programme 6 EUCAARI Integrated Project, Ireland Higher Education Authority Programme for Research in Third Level Institutes - Cycle 5, and the Irish Environmental Protection Agency. NOAA Hysplit and MODIS Ocean Colour website are also acknowledged for providing air mass back trajectories and Chlorophyll map.

Edited by: V.-M. Kerminen

\section{References}

Allan, J. D., Alfarra, M. R., Bower, K. N., Williams, P. I., Gallagher, M. W., Jimenez, J. L., McDonald, A. G., Nemitz, E., Canagaratna, M. R., Jayne, J. T., Coe, H., and Worsnop, D. R.: Quantitative sampling using an Aerodyne aerosol mass spectrometer 2. Measurements of fine particulate chemical composition in two UK cities, J. Geophys. Res., 108(D3), 4091, doi:10.1029/2002JD002359, 2003.

Allan, J. D., Coe, H., Bower, K. N., Alfarra, M. R., Delia, A. E., Jimenez, J.,L., Middlebrook, A.,M., Drewnick, F., Onasch, T. B., Canagaratna, M. R., Jayne, J. T., and Worsnop, D. R.: Technical Note: Extraction of chemically resolved mass spectra from Aaerodyne aerosol mass spectrometer data, J. Aerosol. Sci., 35, 909-922, 2004.

Allan, J. D., Baumgardner, D., Raga, G. B., Mayol-Bracero, O. L., Morales-García, F., García-García, F., Montero-Martínez, G., 
Borrmann, S., Schneider, J., Mertes, S., Walter, S., Gysel, M., Dusek, U., Frank, G. P., and Krämer, M.: Clouds and aerosols in Puerto Rico - a new evaluation, Atmos. Chem. Phys., 8, 12931309, doi:10.5194/acp-8-1293-2008, 2008.

Allan, J. D., Topping, D. O., Good, N., Irwin, M., Flynn, M., Williams, P. I., Coe, H., Baker, A. R., Martino, M., Niedermeier, N., Wiedensohler, A., Lehmann, S., Müller, K., Herrmann, H., and McFiggans, G.: Composition and properties of atmospheric particles in the eastern Atlantic and impacts on gas phase uptake rates, Atmos. Chem. Phys., 9, 9299-9314, doi:10.5194/acp-99299-2009, 2009.

Anderson, T. L., Covert, D. S., Marshall, S. F., Laucks, M. L., Charlson, R. J., Waggoner, A. P., Ogren, J. A., Caldow, R., Holm, R. L., Quant, F. R., Sem, G. J., Wiedensohler, A., Ahlquist, N. A., and Bates, T. S.: Performance characteristics of a high-sensitivity, three-wavelength, total scatter/backscatter nephelometer, J. Atmos. Ocean. Technol., 13, 967-986, 1996.

Andreae, M. O., Jones, C. D., and Cox, P. M.: Strong present-day aerosol cooling implies a hot future, Nature, 435, 1187-1190, 2005.

Baker, A. R. and Croot, P. L.: Atmospheric and marine controls on aerosol iron solubility in seawater, Mar. Chem., 120(1-4), 4-13, 2010.

Bates, T. S., Calhoun, J. A., Quin, P. K.: Variations in the methanesulfonate to sulfate molar ratio in submicrometer marine aerosol particles over the South Pacific Ocean, J. Geophys. Res., 97(D9), 9859-9865, 1992.

Bates, T. S., Quinn, P. K., Coffman, D. J., Johnson, J. E., and Middlebrook, A. M.: Dominance of organic aerosols in the marine boundary layer over the Gulf of Maine during NEAQS 2002 and their role in aerosol light scattering, J. Geophys. Res., 110, D18202, doi:10.1029/2005JD005797, 2005.

Bodhaine, B. A., Ahlquist, N. C., and Schnell, R. C.: 3-Wavelength nephelometer suitable for aircraft measurement of background aerosol scattering coefficient, Atmos. Environ., 25, 2267-2276, 1991.

Berg, O. H., Swietlicki, E., and Krejci, R.: Hygroscopic growth of aerosol particles in the marine boundary layer over the $\mathrm{Pa}-$ cific and Southern Oceans during the first Aerosol Characterization Experiment (ACE 1), J. Geophys. Res.-Atmos., 103(D13), 16535-16545, 1998.

Boers, R., Russchenberg, H., Erkelens, J., and Venema, V.: Ground-based remote sensing of stratocumulus properties during CLARA, 1996, J. Appl. Meteor., 39, 169-181, 2000.

Boers, R., Acarreta, J. R., Gras, and J. L.: Satellite monitoring of the first indirect aerosol effect: Retrieval of droplet concentration of water clouds, J. Geophys. Res., 111, D22208, doi:10.1029/2005JD006838, 2006.

Brandau, C. L., Russchenberg, H. W. J., and Knap, W. H.: Evaluation of ground-based remotely sensed liquid water cloud properties using shortwave radiation measurements, Atmos. Res., 96(23), 366-377, 2010 .

Cavalli, F., Facchini, M. C., Decesari, S., Mircea, M., Emblico, L., Fuzzi, S., Ceburnis, D., Yoon, Y. J., O’Dowd, C. D., Putaud, J. P., and Dell'Acqua, A.: Advances in characterization of size-resolved organic matter in marine aerosol over the North Atlantic, J. Geophys. Res., 109, D24215, doi:10.1029/2004JD005137, 2004.

Canagaratna, M. R., Jayne, J. T., Jimenez, J. L., Allan, J. D., Al- farra, M. R., Zhang, Q., Onasch, T. B., Drewnick, F., Coe, H., Middlebrook, A., Delia, A., Williams, L. R., Trimborn, A. M., Northway, M. J., DeCarlo, P. F., Kolb, C. E., Davidovits, P., and Worsnop, D. R.: Chemical and microphysical characterization of ambient aerosols with the aerodyne aerosol mass spectrometer, Mass Spectrom. Rev., 26(2), 185-222, 2007.

Coe, H., Allan, J. D., Alfarra, M. R., Bower, K. N., Flynn, M. J., McFiggans, G. B., Topping, D. O., Williams, P. I., O’Dowd, C. D., Dall'Osto, M., Beddows, D. C. S., and Harrison, R. M.: Chemical and physical characteristics of aerosol particles at a remote coastal location, Mace Head, Ireland, during NAMBLEX, Atmos. Chem. Phys., 6, 3289-3301, doi:10.5194/acp-6-32892006, 2006.

Crosier, J., Allan, J. D., Coe, H., Bower, K. N., Formenti, P., and Williams, P. I.: Chemical composition of summertime aerosol in the Po Valley (Italy), northern Adriatic and Black Sea, Q. J. Roy. Meteror. Soc., 133, 61-75, 2007.

Dall'Osto, M., Beddows, D. C. S., Kinnersley, R. P., Harrison, R. M., Donovan, R. J., and Heal, M. R.: Characterization of individual airborne particles by using aerosol time-of-flight mass spectrometry at Mace Head, Ireland, J. Geophys. Res., 109, D21302, doi:10.1029/2004JD004747, 2004.

Dall'Osto, M. and Harrison, R. M.: Chemical characterisation of single airborne particles in Athens (Greece) by ATOFMS, Atmos. Environ., 40(39), 7614-7631, 2006.

Dall'Osto, Booth, M., M. J., Smith, W., Fisher, R., and Harrison, R. M.: A study of the size distributions and the chemical characterization of airborne particles in the vicinity of a large integrated steelworks, Aerosol Sci. Technol., 42(12), 981-991, 2008.

Dall'Osto, M., Harrison, R. M., Coe, H., Williams, P. I., and Allan, J. D.: Real time chemical characterization of local and regional nitrate aerosols, Atmos. Chem. Phys., 9, 3709-3720, doi:10.5194/acp-9-3709-2009, 2009.

DeCarlo, P. F., Kimmel, J. R., Trimborn, A., Northway, M. J., Jayne, J. T., Aiken, A. C., Gonin, M., Fuhrer, K., Horvath, T., Docherty, K. S., Worsnop, D. R., and Jimenez, J. L.: Field-deployable, high-resolution, time-of-flight aerosol mass spectrometer, Anal. Chem., 78(24), 8281-8289, 2006.

Decesari, S., Mircea, M., Cavalli, F., Fuzzi, S., Moretti, F., Tagliavini E., and Facchini, M. C.: Source attribution of water-soluble organic aerosol by nuclear magnetic resonance spectroscopy, Environ. Sci. Technol., 41, 2479-2484, 2007.

Drewnick, F., Hings, S. S., DeCarlo, P., Jayne, J. T., Gonin, M., Fuhrer, K., Weimer, S., Jimenez, J. L., Demerjian, K. L., Borrmann, S., Worsnop, D. R.: A new Time-of-Flight Aerosol Mass Spectrometer (TOF-AMS) - instrument description and first field deployment, Aerosol Sci. Technol. 39, 637-658, 2005.

Facchini, M. C., Decesari, S., Rinaldi, M., Mircea, M., Fuzzi, S., Moretti, F., Tagliavini, E., Ceburnis, D., and O'Dowd, C. D.: Important Source of Marine Secondary Organic Aerosol from Biogenic Amines, Environ. Sci. Technol., 42(24), 9116-9121, 2008.

Facchini, M. C., Rinaldi, M., Decesari, S., Carbone, C., Finessi, E., Mircea, M., Fuzzi, S., Ceburnis, D., Flanagan, R., Nilsson, E. D., de Leeuw, G., Martino, M., Woeltjen, J., and O’Dowd, C. D.: Primary submicron marine aerosol dominated by insoluble organic colloids and aggregates, Geophys. Res. Lett., 35, L17814, doi:10.1029/2008GL034210, 2008b.

Frisch, A. S., Feingold, G., Fairall, C. W., Uttal, T., Snider, and J. 
B.: On cloud radar and microwave radiometer measurements of stratus cloud liquid water profiles, J. Geophys. Res., 103, 2319523197, 1998.

Furutani, H., Dall'osto, M., Roberts G. C., and Prather, K. A.: Assessment of the relative importance of atmospheric aging on $\mathrm{CCN}$ activity derived from field observations, Atmos. Environ. 42(13), 3130-3142, 2008.

Gard, E. E., Kleeman, M. J., Gross, D. S., Hughes, L. S., Allen, J. O., Morrical, B. D., Fergenson, D. P., Dienes, T., Galli, M. E., Johnson, R. J., Cass, G. R., and Prather, K. A.: Direct observation of heterogeneous chemistry in the atmosphere, Science, 279(5354), 1184-1187, 1998.

Grenfell, J. L., Harrison, R. M., Allen, A.G., Penkett, S. A., O’Dowd, C. D., Robertson, L., Hewitt, C. N., Davison, B., Lewis, A., Creasey, D., Lee, J., Pilling, M. J., Carpenter, L., and James, J.: An analysis of rapid nanoparticle production at a remote coastal site on the West Irish Coast, J. Geophys. Res., 13771-13780, 1999.

Gross, D. S., Galli, M. E., Silva, P. J., and Prather, K. A.: Relative sensitivity factors for alkali metal and ammonium cations in single particle aerosol time-of-flight mass spectra, Anal. Chem., 72(2), 416-422, 2000.

Gysel, M., McFiggans, G. B., and Coe, H.: Inversion of tandem differential mobility analyser (TDMA) measurements, J. Aerosol Sci., 40, 134-151, 2009.

Hand, J. L. and Malm, W. C. Review of aerosol mass scattering efficiencies from ground-based measurements since 1990, J. Geophys. Res., 112, D16203, doi:10.1029/2007JD008484, 2007.

Heintzenberg, J. and Charlson, R. J.: Design and applications of the integrating nephelometer: A review, J. Atmos. Ocean. Technol., 13, 987-1000, 1996.

Hoppel, W. A., Frick, G. M., and Fitzgerald, J. W.: Marine boundary layer measurements of new particle formation and the effects nonprecipitating clouds have on aerosol size distribution, J. Geophys. Res., 99, 14443-14459, 1994.

Huffman, J. A., Jayne, J. T., Drewnick, F., Aiken, A. C., Onasch, T., Worsnop, D. R., and Jimenez, J. L.: Design, modeling, optimization, and experimental tests of a particle beam width probe for the aerodyne aerosol mass spectrometer, Aerosol Sci. Technol., 39(12), 1143-1163, 2005.

Illingworth, A. J., Hogan, R. J., O'Connor, E. J., Bouniol, D., Brooks, M. E., Delanoe, J., Donovan, D. P., Eastment, J. D., Gaussiat, N., Goddard, J. W. F., Haeffelin, M., Klein Baltink, H., Krasnov, O. A., Pelon, J., Piriou, J.-M., Protat, A., Russchenberg, H. W. J., Seifert, A., Tompkins, A. M., van Zadelhoff, G.-J., Vinit, F., Willen, U., Wilson, D. R., and Wrench, C. L.: CLOUDNET, continuous evaluation of cloud profiles in seven operational models using ground-based observations, B. Am. Meteorol. Soc., 88, 883-898, 2007.

IPCC, 2007, Climate Change 2007: Report of the Intergovernmental Panel on Climate Change, Cambridge University Press, 921 pp., 2007.

Jayne, J. T., Leard, D. C., Zhang, X. F., Davidovits, P., Smith, K. A., Kolb, C. E., and Worsnop, D. R.: Development of an aerosol mass spectrometer for size and composition analysis of submicron particles, Aerosol Sci. Technol., 33(1-02), 49-70, 2000.

Jennings, S. G., Kleefeld, C., O'Dowd, C. D., Junker, C., Gerard Spain, T., O'Brien, P., Roddy, A. F., and O'Connor, T. C.: Mace Head Atmospheric Research Station-characterization of aerosol radiative parameters, Boreal Environ. Res., 8(4), 303-314, 2003. Jennings S. G., Ceburnis D., and Kelly, B. M.: Comparison of aerosol light absorption coefficient measurements at the Mace Head atmospheric research station using a MAAP and an aethalometer, 9th International Conference on Carbonaceous Particles in the Atmosphere, 12-14 August, Berkeley, California, USA, 2008,

Jimenez, J. L., Jayne, J. T., Shi, Q., Kolb, C. E., Worsnop, D. R., Yourshaw, I., Seinfeld, J. H., Flagan, R. C., Zhang, X. F., Smith, K. A., Morris, J. W., and Davidovits, P.: Ambient aerosol sampling using the Aerodyne Aerosol Mass Spectrometer, J. Geophys. Res., 108(D7), 8425, doi:10.1029/2001JD001213, 2003.

Junker, C., Jennings, S. G., and Cachier, H.: Aerosol light absorption in the North Atlantic: trends and seasonal characteristics during the period 1989 to 2003, Atmos. Chem. Phys., 6, 19131925, doi:10.5194/acp-6-1913-2006, 2006.

Kaufman, Y. J., Smirnov, A., Holben, B. N., and Dubovik, O.: Baseline maritime aerosol: methodology to derive the optical thickness and scattering properties, Geophys. Res. Lett., 28(17), 3251-3254, 2001.

Kerminen, V.-M. and Leck, C.: Sulfur chemistry over the central Arctic Ocean during the summer: Gas-to-particle transformation, J. Geophys. Res., 106(D23), 32087-32099, 2001.

Kulmala, M., Asmi, A., Lappalainen, H. K., Carslaw, K. S., Pöschl, U., Baltensperger, U., Hov, Ø., Brenquier, J.-L., Pandis, S. N., Facchini, M. C., Hansson, H.-C., Wiedensohler, A., and O'Dowd, C. D.: Introduction: European Integrated Project on Aerosol Cloud Climate and Air Quality interactions (EUCAARI) - integrating aerosol research from nano to global scales, Atmos. Chem. Phys., 9, 2825-2841, doi:10.5194/acp-9-2825-2009, 2009.

Kunz, G. J., de Leeuw, G., Becker, E., and O'Dowd, C. D.: Lidar observations of atmospheric boundary layer structure and sea spray aerosol plumes generation and transport at Mace Head, Ireland (PARFORCE experiment), J. Geophys. Res., 107(D19), 8106, doi:10.1029/2001JD001240, 2002.

Lance, S., Medina, J., Smith, J. N., and Nenes, A.: Mapping the operation of the DMT Continuous Flow, CCN Counter, Aerosol Sci. Technol., 40, 1-13, doi:10.1080/02786820500543290, 2006.

Lanz, V. A., Alfarra, M. R., Baltensperger, U., Buchmann, B., Hueglin, C., and Prévôt, A. S. H.: Source apportionment of submicron organic aerosols at an urban site by factor analytical modelling of aerosol mass spectra, Atmos. Chem. Phys., 7, 1503-1522, doi:10.5194/acp-7-1503-2007, 2007.

Liu, B. Y. H., Pui, D. Y. H., Whitby, K. T., Kittelson, D. B., Kousaka, Y., and McKenzie, R. L., Aerosol mobility chromatograph - new detector for sulfuric-acid aerosols, Atmos. Environ., 12(1-3), 99-104, 1978.

Maßling, A., Wiedensohler, A., Busch, B., Neusüß, C., Quinn, P., Bates, T., and Covert, D.: Hygroscopic properties of different aerosol types over the Atlantic and Indian Oceans, Atmos. Chem. Phys., 3, 1377-1397, doi:10.5194/acp-3-1377-2003, 2003.

Matta, E., Facchini, M. C., Decesari, S., Mircea, M., Cavalli, F., Fuzzi, S., Putaud, J.-P., and Dell'Acqua, A.: Mass closure on the chemical species in size-segregated atmospheric aerosol collected in an urban area of the Po Valley, Italy, Atmos. Chem. Phys., 3, 623-637, doi:10.5194/acp-3-623-2003, 2003.

Matthew, B. M., Middlebrook, A. M., and, Onasch, T. B.: Col- 
lection efficiencies in an Aerodyne Aerosol Mass Spectrometer as a function of particle phase for laboratory generated aerosols, Aerosol Sci. Technol., 42(11), 884-898, 2008.

Mayol-Bracero, O. L., Guyon, P., Graham, B., Roberts, G., Andreae M. O., Decesari, S., Facchini, M. C., Fuzzi, S., and Artaxo, P.: Water-soluble organic compounds in biomass burning aerosols over Amazonia: 2. Apportionment of the chemical composition and importance of the polyacidic fraction, J. Geophys. Res., 107(D20), 8091, doi:10.1029/2001JD000522, 2002.

McArdle, N., Liss, P., and Dennis, P.: An isotopic study of atmospheric sulphur at three sites in Wales and at Mace Head, Eire, J. c, 103(D23), 31079-31094, 1998.

McArthur, L. J. B., Halliwell, D. H., Niebergall, O. J., O’Neill, N. T., Slusser, J. R., and Wehrli, C.: Field comparison of network sun photometers, J. Geophys. Res., 108(D19), AAC 1-1, 4596, doi:10.1029/2002JD002964, 2003.

Mulcahy, J. P., O’Dowd, C. D., Jennings, S. G., and Ceburnis, D.: Significant enhancement of aerosol optical depth in marine air under high wind conditions, J. Geophys. Res. Lett., 35, L16810, doi:10.1029/2008GL034303, 2008.

Mulcahy, J. P., O’Dowd, C. D., Jennings, and S. G.: Aerosol optical depth in clean marine and continental northeast Atlantic air, J. Geophys. Res., 114, D20204, doi:10.1029/2009JD011992, 2009.

Murphy, D. M.: The design of single particle laser mass spectrometers. Mass Spectrom. Rev., 26(2), 150-165, 2007.

Nilsson, E. D., Rannik, U., Buzorius, G., O'Dowd, C. D.: Effects of continental boundary layer evolution, convection, turbulence and entrainment on aerosol formation, Tellus B, 53, 441-461, 2001.

Nilsson, E., Swietlicki, E., Sjogren, S., Löndahl, J., Nyman, M., and Svenningsson, B.: Development of an H-TDMA for longterm unattended measurement of the hygroscopic properties of atmospheric aerosol particles, Atmos. Meas. Tech., 2, 313-318, doi:10.5194/amt-2-313-2009, 2009.

O'Connor, T. C., Jennings, S. G., and O'Dowd, C. D.: Highlights from 50 years of Aerosol Measurements at Mace Head, Atmos. Res., 90, 338-355, doi:10.1016/j.atmosres.2008.08.014, 2008.

O’Dowd, C. D., Smith, M. H., and Jennings, S. G.: Submicron aerosol, radon and soot carbon characteristics over the northeast Atlantic, J. Geophys. Res., 98, 1123-1135, 1993.

O’Dowd, C. D., Geever, M., Hill, M. K., Jennings, S. G., Smith, M. H.: New particle formation: Spatial scales and nucleation rates in the coastal environment, Geophys. Res. Letts, 25, 1661-1664, 1998.

O’Dowd, C. D., McFiggens, G., Pirjola, L., Creasey, D. J., Hoell, C., Smith, M. H., Allen, B., Plane, J. M. C., Heard, D. E., Lee, J. D., Pilling, M. J., and Kulmala, M.: On the photochemical production of new particles in the coastal boundary layer, Geophys. Res. Lett., 26, 1707-1710, 1999.

O'Dowd, C. D., Lowe, J., Smith, M. H., and Kaye, A. D.: The relative importance of sea-salt and nss-sulphate aerosol to the marine CCN population: An improved multi-component aerosoldroplet parameterisation, Q. J. Roy. Meterol. Soc., 125, 12951313, 1999.

O'Dowd, C. D., Becker, E., and Kulmala, M.: Mid-latitude NorthAtlantic aerosol characteristics in clean and polluted air, Atmos. Res., 58(3), 167-185, 2001.

O’Dowd, C. D., Hämeri, K., Mäkelä, J. M., Pirjola, L., Kulmala, M., Jennings, S. G., Berresheim, H., Hansson, H.-C., de Leeuw, G., Allen, A. G., Hewitt, C. N., Jackson, A., Viisanen, Y., Hoff- mann, T.: A dedicated study of new particle formation and fate in the coastal environment (PARFORCE): Overview of objectives and initial achievements, J. Geophys. Res., 107(D19), 8108, doi:10.1029/2001JD000555, 2002.

O’Dowd, C. D., Facchini, M. C., Cavalli, F., Ceburnis, D., Mircea, M., Decesari, S., Fuzzi, S., Yoon, Y. J., and Putaud, J. P.: Biogenically driven organic contribution to marine aerosol, Nature, 431, 676-680, 2004.

Paatero, P.: Least squares formulation of robust non-negative factor analysis, Chemometr. Intell. Lab., 37, 23-35, 1997.

Phinney, L., Leaitch, W. R., Lohmann, U., Boudries, H., Worsnop, D. R., Jayne, J. T., Toom-Sauntry, D., Wadleigh, M., Sharma, S., and Shantz, N.: Characterization of the aerosol over the subarctic north east Pacific Ocean, Deep-Sea Research - Part II: Topical Studies, Oceanography, 53(20-22), 2410-2433, 2006.

Pope, C. A. and Dockery, D. W.: Health effects of fine particulate air pollution: Lines that connect, J. Air Waste Manage., 56(6), 709-742, 2006.

Quinn, P. K., Kapustin, V. N., Bates, T. S., and Covert, D. S.: Chemical and optical properties of marine boundary layer aerosol particles of the mid-Pacific in relation to sources and meteorological transport, J. Geophys. Res.-Atmos., 101(D3), 6931-6951, 1996.

Quinn, P. K., Coffman, D. J., Bates, T. S., Miller, T. L., Johnson, J. E., Voss, K., Welton, E. J., and Neususs, C.: Dominant aerosol chemical components and their contribution to extinction during the Aerosols 99 cruise across the Atlantic, J. Geophys. Res.Atmos., 106(D18), 20783-20809, 2001.

Rader, D. J. and McMurry, P. H.: Application of the tandem differential mobility analyzer to studies of droplet growth or evaporation, J. Aerosol Sci., 17(5), 771-787, 1986.

Rinaldi, M., Emblico, L., Decesari, S., Fuzzi, S., Facchini, M. C., and Librando, V.: Chemical Characterization and Source Apportionment of Size-Segregated Aerosol Collected at an Urban Site in Sicily, Water Air Soil Poll., 185, 311-321, 2007.

Savoie, D. L., Arimoto, R., Keene, W. C., Prospero, J. M., Duce, R. A., and Galloway, J. N.: Marine biogenic and anthropogenic contributions to non-sea-salt sulfate in the marine boundary layer over the North Atlantic Ocean, J. Geophys. Res., 107(D18), 4356, doi:10.1029/2001JD000970, 2002.

Seinfeld, J. H. and Pandis, S. N.: Atmospheric chemistry and physics - from air pollution to climate change, New York, Wiley Interscience, 1998.

Sellegri, K., O’Dowd, C. D., Yoon, Y. J., Jennings, S. G., and de Leeuw, G.: Surfactants and submicron sea spray generation, J. Geophys. Res.-Atmos., 111(D22) , D22215, doi:10.1029/2005JD006658(AGU), 2006.

Sellegri, K., Villani, P., Picard, D., Dupuy, R., O’Dowd, C. D., and Laj, P.: Role of the volatile fraction of submicron marine aerosol on its hygroscopic properties, Atmos. Res., 90(2-4), 272-277, 2008.

Smirnov, A., Holben, B. N., Eck, T. F., Dubovik, O., and Slutsker,I.: Effect of wind speed on columnar aerosol optical properties at Midway Island, J. Geophys. Res., 108, 4802, doi:10.1029/2003JD003879, 2003.

Song, X. H., Hopke, P. K., Fergenson, D. P., and Prather, K. A.: Classification of single particles analyzed by ATOFMS using an artificial neural network, ART-2A, Anal. Chem., 71(4), 860-865, 1999.

Swietlicki, E., Zhou, J. C., Covert, D. S., Hameri, K., Busch, B., 
Vakeva, M., Dusek, U., Berg, O. H., Wiedensohler, A., Aalto, P., Makela, J., Martinsson, B. G., Papaspiropoulos, G., Mentes, B., Frank, G., and Stratmann, F.: Hygroscopic properties of aerosol particles in the northeastern Atlantic during ACE-2, Tellus B, 52(2), 201-227, 2000.

Tang, I. N. and Munkelwitz, H. R.: Water activities, densities, and refractive indices of aqueous sulphates and sodium nitrate droplets of atmospheric importance, J. Geophys. Res., 99(D9), 18801-18808, 1994.

Ulbrich, I. M., Canagaratna, M. R., Zhang, Q., Worsnop, D. R., and Jimenez, J. L.: Interpretation of organic components from Positive Matrix Factorization of aerosol mass spectrometric data, Atmos. Chem. Phys., 9, 2891-2918, doi:10.5194/acp-9-2891-2009, 2009.

Villevalde, Y. V., Smirnov, A. V., Oneill, N. T., Smyshlyaev, S. P., and Yakovlev, V. V.: Measurement of aerosol optical depth in the Pacific-Ocean and the North-Atlantic, J. Geophys. Res.-Atmos., 99(D10), 20983-20988, 1994.

Wang, S. C., and Flagan, R. C.: Scanning electrical mobility spectrometer, Aerosol Sci. Technol., 13, 230-240, doi:10.1080/02786829008959441, 1990.
Yoon, Y. J., Cheevers, S., Jennings, S. G., and O'Dowd, C. D.: Performance of a venturi dilution chamber for sampling 3-20 nm particles, J. Aerosol. Sci., 36, 535-540, 2005.

Yoon, Y. J., Ceburnis, D., Cavalli, F., Jourdan, O., Putaud, J. P., Facchini, M. C., Decesari, S. Fuzzi, S., Sellegri, K., Jennings, S. G. and O'Dowd, C. D.: Seasonal characteristics of the physico-chemical properties of North Atlantic marine atmospheric aerosols, J. Geophys. Res., 112, D04206, doi:10.1029/2005JD007044, 2007.

Ziemba, L. D., Fischer, E., Griffin, R. J., and Talbot, R. W.: Aerosol acidity in rural New England: Temporal trends and source region analysis, J. Geophys. Res., 112, D10S22, doi:10.1029/2006JD007605, 2007.

Zorn, S. R., Drewnick, F., Schott, M., Hoffmann, T., and Borrmann, S.: Characterization of the South Atlantic marine boundary layer aerosol using an aerodyne aerosol mass spectrometer, Atmos. Chem. Phys., 8, 4711-4728, doi:10.5194/acp-8-47112008, 2008. 